\title{
Candida albicans Interactions with Mucosal Surfaces during Health and Disease
}

\author{
Spyridoula-Angeliki Nikou ${ }^{1}$, Nessim Kichik ${ }^{2}$, Rhys Brown ${ }^{2}$, Nicole O. Ponde ${ }^{2}$, Jemima Ho ${ }^{2}$, \\ Julian R. Naglik ${ }^{2}$ and Jonathan P. Richardson $2, *$ (I) \\ 1 Protein Phosphorylation Laboratory, The Francis Crick Institute, London NW1 1AT, UK; \\ spyridoula.nikou@crick.ac.uk \\ 2 Centre for Host-Microbiome Interactions, Faculty of Dentistry, Oral \& Craniofacial Sciences, King's College \\ London, London SE1 1UL, UK; nessim.kichik@kcl.ac.uk (N.K.); rhys.brown@kcl.ac.uk (R.B.); \\ nicole.ponde@kcl.ac.uk (N.O.P.); jemima.ho@kcl.ac.uk (J.H.); julian.naglik@kcl.ac.uk (J.R.N.) \\ * Correspondence: jonathan.richardson@kcl.ac.uk; Tel.: +44-20-7848-6121
}

Received: 28 February 2019; Accepted: 15 April 2019; Published: 22 April 2019

\begin{abstract}
Flexible adaptation to the host environment is a critical trait that underpins the success of numerous microbes. The polymorphic fungus Candida albicans has evolved to persist in the numerous challenging niches of the human body. The interaction of $C$. albicans with a mucosal surface is an essential prerequisite for fungal colonisation and epitomises the complex interface between microbe and host. C. albicans exhibits numerous adaptations to a healthy host that permit commensal colonisation of mucosal surfaces without provoking an overt immune response that may lead to clearance. Conversely, fungal adaptation to impaired immune fitness at mucosal surfaces enables pathogenic infiltration into underlying tissues, often with devastating consequences. This review will summarise our current understanding of the complex interactions that occur between C. albicans and the mucosal surfaces of the human body.
\end{abstract}

Keywords: Candida albicans; commensal; pathogen; fungus; mucosal infection; microbiota

\section{Introduction}

The human body provides a multitude of disparate and challenging niches to colonising microbes, including the mucosal surfaces of the oropharyngeal, gastrointestinal and vaginal tracts. Candida albicans has evolved to persist at mucosal surfaces [1,2] as a benign component of the microbiota, and is superbly adapted to life in the host as a commensal organism, particularly in the gastrointestinal tract. While frequently colonised by C. albicans, mucosal surfaces nevertheless play a vital role in host protection and are crucial for the appropriate initiation and coordination of innate immune responses during infection. However, under circumstances where host immunity is impaired, C. albicans can transition from a harmless commensal to a pathogen capable of breaching mucosal barriers, causing deep seated invasive and life-threatening disseminated infection.

Coevolution of $C$. albicans with the human host has resulted in both organisms acquiring the means to adapt to one another. This coevolutionary "coin" comprises continual fungal adaptation to the host on one side, and a perpetual evolution of the host immune response to the fungus on the other. While the majority of scientific studies have focused on C. albicans hyphae and associated virulence factors, both yeast and hyphal morphologies contribute to fungal persistence in the host. A physical interaction between $C$. albicans and a mucosal surface is a necessary requirement that precedes commensal colonisation and pathogenic infiltration.

This review article will examine the numerous events that transpire during the interaction of C. albicans with the mucosal surfaces of the human body; mechanistic and structural aspects of adhesion 
will be considered together with the processes of epithelial internalisation, the role of secreted host and fungal factors, and the acquisition of essential micronutrients.

\section{Adhesion of C. albicans to the Epithelium}

Adhesion of $C$. albicans to a mucosal surface is an essential requirement for persistence in the host, whether it be as a commensal or a pathogen $[3,4]$. The mucosal surfaces of the body are covered with a protective coating of mucous which must be traversed in order for C. albicans to attach itself to underlying epithelial cells. Indeed, adhesion of C. albicans to buccal epithelial cells is reduced in the presence of purified mucin [5]. The majority of initial contact between C. albicans and the host is thought to involve yeast, with germ tube and hypha formation occurring after initial contact. Yeast cells have evolved a number of strategies to ensure successful adherence to the host epithelium. Initial interactions between C. albicans and epithelial cells rely on a number of attractive and repulsive forces, including van der Waals forces and hydrophobic interactions [6]. While these passive forces are by no means the predominant mechanism required for long-term fungal adhesion, they are nevertheless vital for the initiation of adherence. C. albicans and epithelial cells are considered to possess a net negative charge, implying a degree of electrostatic repulsion that opposes physical association [7]. Successful contact between C. albicans and epithelial cells is thus dependent on the sum of attractive forces outweighing those which promote cellular repulsion [8]. Adhesion of yeast cells to epithelial cells positively correlates with the expression of cell surface hydrophobins $[9,10]$, while cetylpyridinium chloride-induced reduction of cell surface hydrophobicity correlates with decreased adhesion [11].

Once attached to the mucosal surface, the adhesion of $C$. albicans is further strengthened by numerous interactions with components of the host extracellular matrix. C. albicans yeast can bind to human fibronectin [12,13], proline-rich salivary proteins [14] and carbohydrates that facilitate adhesion to human oesophageal epithelial cells [15] and buccal epithelial cells in vitro [16].

However, the greatest contribution to fungal adhesion is conferred by the adhesins. The best studied of the C. albicans adhesins are the agglutinin-like sequence (Als) family of proteins; consisting of eight members (Als1p-Als7p and Als9p) that are glycosylphosphatidylinositol (GPI)-linked to the $\beta-1,6$-glucans of the fungal cell wall (reviewed in [17]). Als5p mediates the initial adhesion of $C$. albicans yeast cells to human buccal epithelial cells, and to patches of threonine, serine, and alanine residues within fibronectin, type IV collagen and laminin [18-20]. A conserved tandem repeat region within Als5p facilitates adhesion to numerous epithelial ligands and promotes yeast-to-yeast cell aggregation [21,22]. The conserved amyloid forming sequences of Als5p are implicated in a transition away from overt pathogenicity towards gastrointestinal commensalism in vivo [23] and are important for coordinating the clustering of adhesins on the C. albicans fungal cell wall, facilitating continued fungal adhesion to the host by increasing the likelihood of epithelial cell ligands rebinding to nearby adhesins should detachment occur [24,25].

Expression of ALS genes differs according to fungal morphology and body site. ALS1-5 and ALS9 were consistently upregulated in a reconstituted human buccal epithelium model of mucocutaneous candidiasis, while ALS6 and ALS7 exhibited variable expression. In contrast, ALS1, ALS2, ALS3 and $A L S 9$ were expressed frequently in clinical specimens of vaginal fluid, while transcripts from ALS4 and ALS5 were detected less frequently [26]. This differential expression not only suggests a degree of functional redundancy between Als adhesins but suggests specific roles for particular adhesins at different mucosal sites [27]. The factors that contribute to the adhesion of $C$. albicans yeast to epithelial cells are depicted in Figure 1A. 


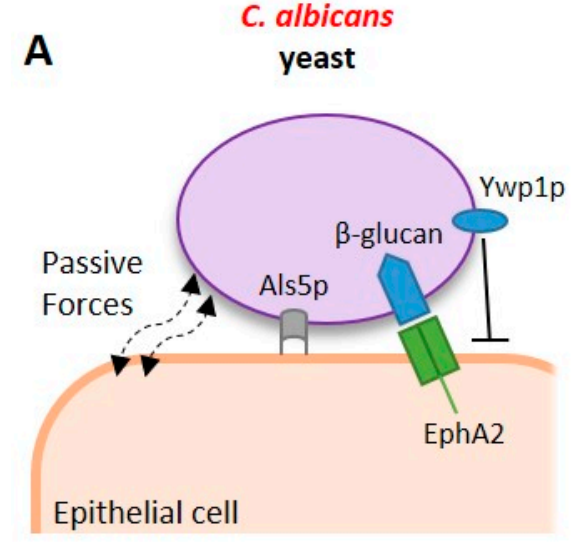

C

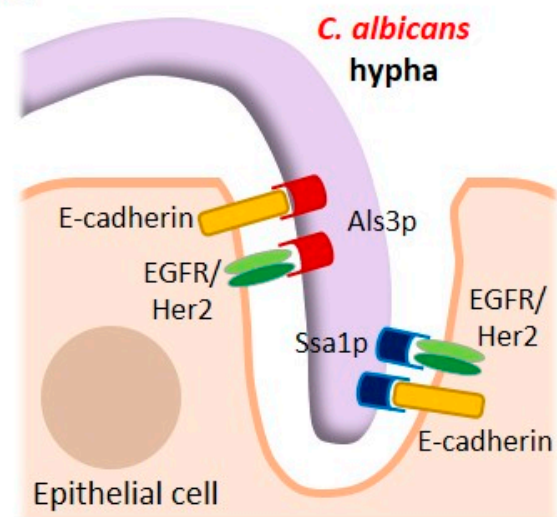

B

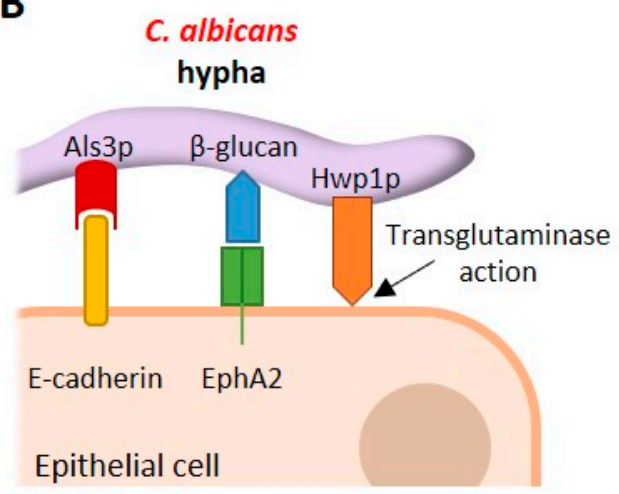

D

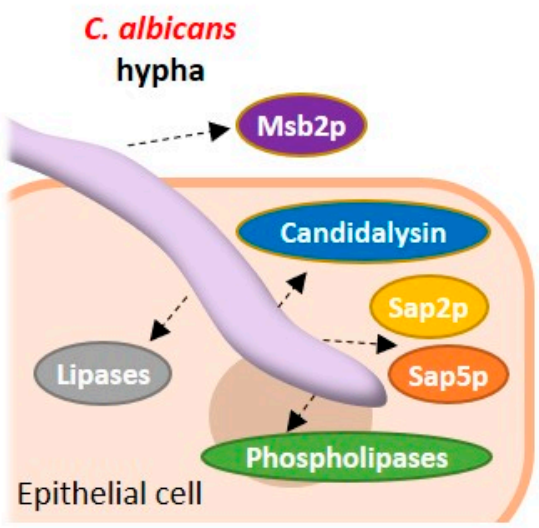

Figure 1. Interactions of Candida albicans with host epithelial cells. (A) C. albicans yeast cells use the passive forces of electrostatic attraction and specific genome-encoded factors such as agglutinin-like sequence 5 (Als5p) to adhere to epithelial cells. Yeast-phase beta glucan is recognised by the nonclassical pattern recognition receptor EphA2 during this initial interaction. Ywp1p is expressed during yeast-phase growth and has antiadhesive properties. A host receptor for Ywp1p has not yet been identified. (B) Once attached to the mucosal surface the transition to the hyphal morphology results in the expression of additional adhesins including Als3p and Hwp1p, which further consolidate epithelial adhesion by interacting with E-cadherin and acting as a substrate for host transglutaminase enzymes, respectively. Hyphal beta glucan is also recognised by EphA2 during this strengthened adherence. (C) Epithelial internalisation of C. albicans hyphae is mediated by the Als3p and Ssa1p invasins which interact with E-cadherin and a heterodimeric receptor complex comprising the epidermal growth factor receptor (EGFR) and Her2 (EGFR/Her2). C. albicans remains passive during this process of pathogen-induced endocytosis but may also breach mucosal barriers directly by active penetration. (D) While in contact with the mucosal surface, C. albicans secretes an arsenal of virulence factors including the peptide toxin candidalysin, secreted aspartic proteinases (Saps), lipases and phospholipases that facilitate pathogenicity. Msb2p is released into the extracellular environment to counteract the activity of numerous host antimicrobial peptides.

Of the Als proteins, Als3p is key in the adherence of C. albicans hyphae to epithelial cells and the subsequent invasion of host cells. ALS3 is upregulated during infection of oral and vaginal epithelial cells [26,28-30] while blocking Als3p or preventing ALS3 expression causes a significant reduction in epithelial adhesion $[17,31]$.

However, the role of certain Als proteins in C. albicans-epithelial interaction is less clear. For instance, while deletion of ALS1 caused a significant decrease in fungal adhesion to murine tongue tissue ex vivo [32] reports also suggest that Als1p plays only a minor role in adhesion, particularly when 
compared with Als3p [33]. Similarly, while deletion of ALS2 decreased the adhesion of C. albicans to a reconstituted model of human oral epithelium, deletion of ALS4 in the same model had no effect [34].

Given the degree of functional redundancy observed between adhesins and the inherent complexity associated with adhesion of $C$. albicans to a diverse range of host tissues, it is perhaps unsurprising that the process of adhesion is subject to numerous influential forces. Indeed, several antiadhesive factors have been identified which may serve to fine-tune the process of adhesion. Yeast wall protein $1(Y w p 1 p / P g a 24 p)$ is a yeast-specific GPI-linked glycoprotein that is highly expressed during yeast but not hyphal growth [35]. Deletion studies demonstrate that yeast cells lacking YWP1 are more adhesive [36,37], suggesting a role for Ywp1p in the dispersal of yeast, which may facilitate dissemination [37]. Deletion of ALS5, ALS6 and ALS7 increase adhesion to epithelial cells, suggesting that these proteins also possess antiadhesive properties [38]. The major factors that contribute to the adhesion of C. albicans hyphae to epithelial cells are depicted in Figure 1B.

\section{Structural and Mechanistic Aspects of Adhesion to the Epithelial Surface}

Adhesion is a complex process that results from the simultaneous interaction of fungal cell wall components with the biomolecules present on the surface of the host cell membrane. While the fungal cell wall is composed of proteins and carbohydrates (chitin, glucan and mannans), the composition of proteins and sugars differs between yeast and hyphal morphologies. In hyphae, adhesins and proteins involved in cell wall synthesis are upregulated resulting in stronger adhesion when compared to yeast [39].

While most studies investigating C. albicans adhesion have used genetic approaches, relatively little is known about the structural basis of adhesion to epithelial cells. Hyphal regulated 1 (Hyr1p), hyphal wall protein 1 (Hwp1p) and the Als proteins share a similar arrangement of domains; a folded $\mathrm{N}$-terminal domain responsible for protein-protein/ligand interaction with the host followed by a serine/threonine-rich variable tandem domain of low complexity and a C-terminal peptide sequence that covalently binds to a GPI lipid anchor in the fungal cell wall [40]. However, no structural information is available for Hyr1p and Hwp1p adhesins at present.

The N-terminal domain of Hwp1p exhibits $40-50 \%$ amino acid sequence identity with the central and N-terminal domains of the human small proline-rich (SPR) family of proteins which are substrates of the transglutaminase (TGase) family of enzymes. At the interface between the $C$. albicans cell wall and the epithelial cell membrane, host TGases cross-link Hwp1p to lysine residues within the proteins present on the epithelial surface [41].

Our understanding of the structure-function relationship that enables adhesion to the host is most advanced for the Als family of adhesins [42,43], which recognise and bind to a variety of structurally unrelated ligands. Such flexibility enables $C$. albicans to attach to surfaces with different compositions including bacterial and mammalian cells and to abiotic surfaces such as medical devices [44]. Numerous Als binding proteins have been identified including Streptococcus gordonii SspB, bovine serum albumin, gp96, collagen, laminin, casein, fibrinogen, human and equine ferritin and the human epidermal growth factor receptors EGFR/HER1 and HER2, fibronectin, E-cadherin and N-cadherin [20,28,29,45-48].

An X-ray crystal structure of the N-terminal domain of an allelic variant of Als9p (designated Als9-2) complexed with the C-terminal region of human fibrinogen- $\gamma$ reveals that the Als adhesins recognise flexible $\mathrm{C}$-terminal peptides of up to six amino acids which are accommodated in an extended conformation inside a peptide binding cavity (PBC) [49]. A model describing how Als adhesins recognise and bind structurally unrelated ligands has been proposed, in which the wide, flat $\mathrm{PBC}$ located in the $\mathrm{N}$-terminal domain of the Als adhesin can accommodate a wide range of 6-mer peptide ligands [50]. Once located in the PBC, the peptide backbone of the ligand forms an extensive network of hydrogen bonds with the residues of the PBC and a salt bridge is formed between the C-terminal carboxylic acid of the incoming peptide and the positively charged side chain of a conserved lysine located at the end of the PBC. However, most transmembrane-spanning proteins typically have their free C-termini located on the intracellular face of the plasma membrane, rendering them inaccessible to 
the PBC of Als adhesins. To mitigate this issue, a mechanism was proposed in which secretion of fungal proteinases enables limited proteolytic digestion of the extracellular regions of membrane-associated host proteins, liberating free C-termini on the extracellular face of the plasma membrane that may subsequently be recognised by the PBC [51]. However, it must also be noted that Als1p and Als5p are capable of binding to peptides displaying free $\mathrm{N}$ - or C-termini [20,52].

The Als family of proteins also contain an amyloid forming region (AFR), located in the $\mathrm{N}$-terminal domain. Als proteins can interact with each other via their AFR motifs to form large molecular weight clusters of Als proteins, termed nanodomains [53,54], which are implicated in the aggregation of C. albicans hyphae, biofilm formation and cell adhesion. Furthermore, the interaction between soluble regions of AFR motifs in Als5p results in the formation of amyloid fibers [53]. Analysis of AFR motifs by nuclear magnetic resonance (NMR) spectroscopy demonstrate that Als proteins interact with each other via their AFR domains to form Als aggregates in the absence of ligands. However, in the presence of ligands that bind to the PBC these interactions are disrupted. These findings highlight that ligand binding and Als-Als aggregation are mechanistically distinct. Disruption of the PBC but not the AFR results in decreased fungal adhesion to the commensal bacterium S. gordonii, suggesting that the PBC of Als3p plays a primary role in mediating the interaction between C. albicans and microbial cells whereas the AFR motif is necessary for Als-Als clustering in the absence of Als ligands [50,51].

\section{The Commensal Relationship with the Host}

C. albicans is exquisitely adapted to life in the host as a commensal, particularly in the gastrointestinal tract. This continually evolving commensal relationship between C. albicans and the human body is typified by asymptomatic carriage. While commensal colonisation of mucosal surfaces is often associated with yeast rather than hyphae, both morphologies have been observed to colonise the murine gastrointestinal tract [55].

Mouse models of gastrointestinal colonisation demonstrate that $C$. albicans can stably colonise the gastrointestinal tract in a little as three days [56]. The mitogen-activated protein kinase Hog1p confers adaptation to oxidative and osmotic stress, and is essential for gastrointestinal colonisation [57] while numerous transcriptional regulators, including Tye7p, Lys144p, Hms1p, Rtg1p, Rgt3p and ORF19.3625, play a significant role in colonisation [58].

Recently, significant advances in our understanding of the fine balance between beneficial and detrimental antifungal immune responses have been made. Commensal colonisation of the host intestine drives the expansion of systemic Th17 CD4 ${ }^{+} \mathrm{T}$ cells that, together with IL-17-responsive neutrophils, protect against invasive infection [59]. However, colonisation was observed to exacerbate susceptibility to allergic airway inflammation [59]. Indeed, the process of intestinal inflammation drives the expansion of $C$. albicans-specific Th17 cells and a pool of Th17 cells that exhibit cross-reactivity to Aspergillus fumigatus in patients with airway inflammation and acute allergic bronchopulmonary aspergillosis [60], establishing a link between protective immunity in the gut and immune pathology in the lung $[59,60]$.

The C. albicans transcription factor enhanced filamentous growth 1 (Efg1p) is a major regulator of commensal colonisation in healthy and immune compromised mice. In vivo competition experiments between wild type $C$. albicans and an $e f g 1 \Delta / \Delta$ null mutant strain in healthy (immune competent) mice demonstrate that fungi lacking EFG1 have an increased propensity to colonise the gastrointestinal tract at early time points (up to $24 \mathrm{~h}$ ), which is not sustained at later time points [61]. EFG1 gene expression in wild type $C$. albicans isolated from the caecum or ileum of wild type BALB/c mice was low during the initial stages of gastrointestinal colonisation (within $3 \mathrm{~d}$ ) but increased over time up to $18 \mathrm{~d}$. In contrast, EFG1 gene expression in wild type C. albicans isolated from T cell-deficient nu/nu mice was consistently low at all time points analysed [61]. Thus, variations in the level of EFG1 expression within colonising populations of fungi are proposed to reflect an adaptation to the degree of fitness between healthy and compromised hosts, facilitating the transition from commensal to pathogenic behaviour [61]. 
Indeed, EFG1 gene dosage has a profound effect on phenotypic plasticity and C. albicans commensalism [62]. Many clinical isolates of C. albicans are hemizygous for EFG1 (EFG1/efg1) and undergo a transition from the white to grey state via a mechanism that involves loss of EFG1 function, resulting in enhanced fitness in the gastrointestinal tract [62].

C. albicans is inordinately responsive to the stresses it frequently encounters and has evolved to use these environmental cues as a means to persist in the host. Passage of $C$. albicans through the murine gastrointestinal tract induces a white-opaque regulator (Wor1p)-dependent switch to the gastrointestinal induced transition (GUT) phenotype that promotes commensalism [63], while C. albicans opaque cells exhibit increased colonisation of skin compared to white cells [64].

Very recently, competitive infection experiments between wild type C. albicans and a large panel of null mutant strains in a murine model of gastrointestinal colonisation have revealed that the hyphal gene network that promotes virulence causes an inhibition of commensal fitness [55]. Five transcription factor null mutants ( $\operatorname{brg} 1 \Delta / \Delta, e f g 1 \Delta / \Delta, \operatorname{rob} 1 \Delta / \Delta, \operatorname{tec} 1 \Delta / \Delta$ and ume $6 \Delta / \Delta)$ exhibited enhanced colonisation fitness when compared to an isogenic wild type control strain suggesting that commensal fitness in the gut is inversely related to the expression of genes required for the coordination of morphogenesis [55]. Notably, Ume6p-mediated inhibition of gut colonisation required the activation of the secreted aspartic proteinase Sap6p and, to a lesser extent, Hyr1p [55].

The apparent antagonism between hyphal growth and commensalism is further underpinned by the observation that serial passage of $C$. albicans through the murine gastrointestinal tract promotes adaptive evolution resulting in the loss of hypha-forming ability in the absence of a competitive microbiota [65]. Gut-evolved C. albicans strains that lost the ability to form hyphae exhibited reduced virulence in vitro and in vivo. Strikingly, mice "primed" with evolved C. albicans received substantial innate protection against systemic infection with Aspergillus fumigatus, Staphylococcus aureus and Pseudomonas aeruginosa [65].

\section{Invasion of the Mucosal Surface}

Mucosal internalisation of $C$. albicans requires a number of host and pathogen-derived factors but remains incompletely understood. There are two main mechanisms of $C$. albicans internalisation. Induced endocytosis describes a process where C. albicans remains completely passive during its uptake into host cells, such that metabolically nonviable fungi are still endocytosed. The mechanism is clathrin-dependent and requires actin cytoskeleton remodelling [66]. Induced endocytosis can be instigated by the binding of host E-cadherin or EGFR/Her2 complexes to the fungal invasins Ssa1p or Als3p. Studies show that latex beads coated with the N-terminal region of Als3p are successfully internalised [28], while inhibition of EGFR/Her2 activity significantly reduces the severity of oropharyngeal candidiasis (OPC) [29]. Other proteins with a role in C. albicans endocytosis include host GTPases and zonula occludens- 1 which are associated with actin remodelling during infection [67], the aryl hydrocarbon receptor (AhR), thought to govern EGFR-induced endocytosis [68], platelet-derived growth factor BB (PDGF BB) and neural precursor cell expressed developmentally downregulated protein 9 (NEDD9), which are important for host-induced uptake of fungus [69]. The major factors that contribute to the process of induced endocytosis of $C$. albicans hyphae are depicted in Figure 1C.

Active penetration by $C$. albicans results in direct breach of the epithelium, with hyphae extending through individual epithelial cells or between them. Unlike induced endocytosis, this process is dependent on C. albicans morphology, where the maintenance of turgor pressure and continued extension of hyphal tips play important roles. Although the presence of $C$. albicans in the gastrointestinal tract is closely associated with commensal carriage, translocation across the gastrointestinal mucosa positively correlates with systemic infection [70-72]. Recent research has demonstrated that the predominant route of gastrointestinal translocation by C. albicans is transcellular rather than paracellular (occurring through epithelial cells as opposed to between them), a process that is facilitated by the peptide toxin candidalysin [73]. Additionally, fungal secreted aspartic proteases 2 (Sap2p) and Sap5p, 
which degrade gastrointestinal mucins [74] and E-cadherin [75], respectively, may also facilitate the translocation of $C$. albicans across the epithelium. Though active penetration was considered to be the only mechanism of $C$. albicans internalisation at the gastrointestinal epithelium [76], recent evidence suggests that a host facilitated method may also occur that is dependent on gut $\mathrm{M}$ cells [77]. Perhaps unsurprisingly, many of the host proteins that govern fungal invasion possess functions in maintaining the epithelium highlighting the significance of epithelial barrier integrity in protection against $C$. albicans infection [78].

\section{Epithelial Recognition of C. albicans}

The first step in developing an innate immune response against $C$. albicans is host recognition. The cells that comprise mucosal barriers express pattern recognition receptors (PRRs) that recognise pathogen-associated molecular patterns (PAMPs) such as fungal cell wall components present on yeast and hyphal cells [79]. There are three main classes of PRR expressed in innate myeloid cells associated with fungal infections: the toll-like receptors (TLRs), the C-type lectin receptors (CLRs) and the NOD-like receptors (NLRs). Of these, TLRs and CLRs are expressed in epithelial cells [80-82]. TLRs comprise an extracellular domain rich in leucine repeats required for recognition of microbial structures, and a cytoplasmic Toll/IL-1 receptor (TIR) domain that is responsible for intracellular signalling $[80,83,84]$. Of all TLRs, only TLR5 and TLR7 are not detectable in human buccal epithelial cells from healthy donors. Epithelial cells interact with C. albicans through TLR1-4 and TLR6 [85-88], with TLR4 being induced during oral candidiasis and TLR2 during vulvovaginal candidiasis $[86,89]$.

CLRs recognise polysaccharide structures on microbes and are probably the most important receptors that mediate fungal recognition in macrophages, dendritic cells and neutrophils. Dectin-1 is a $\beta$-glucan receptor and constitutes one of the major CLRs in myeloid cells found to be important in systemic infections [90-92]. Although dectin- 1 can bind to the $\beta$-glucan present on yeast phase C. albicans [93], infection of TR146 epithelial cells with C. albicans for $24 \mathrm{~h}$ resulted in a downregulation of dectin-1 gene expression [94]. Indeed, dectin-1 is thought to play only a minor role in the oral epithelial response to $C$. albicans [87]. In contrast, a nonsense mutation in dectin-1 (Y238STOP) is associated with recurrent vulvovaginal candidiasis (RVVC) [95] suggesting a protective role for dectin-1 in the vaginal response to C. albicans.

Recently, the ephrin type-A receptor 2 (EphA2) was identified as a nonclassical epithelial PRR that recognises the $\beta$-glucans present on C. albicans yeast and hyphae [93]. Activation of EphA2 was observed within $15 \mathrm{~min}$ in response to yeast phase $C$. albicans and $90 \mathrm{~min}$ for hyphae, with subsequent activation of signal transducer and activator of transcription 3 (STAT3), mitogen-activated protein kinase (MAPK) and nuclear factor kappa-light-chain-enhancer of activated B cells (NF- $\mathrm{kB}$ ) signalling and a proinflammatory and antifungal response at $24 \mathrm{~h}$ [93]. These findings suggest a role for EphA2 in the initial interaction between C. albicans and epithelial cells, most likely to prime mucosal tissues for subsequent induction of appropriate immune responses to hyphal factors released later during mucosal infection.

Epithelial cells discriminate between harmless commensalism and invasive hyphae via a biphasic activation of the MAPK immune pathway [96,97]. Recognition of commensal yeast comprises the first phase of the biphasic epithelial response, resulting in a weak activation of the NF- $\mathrm{KB}$, phosphoinositide 3-kinase (PI3K), c-Jun N-terminal kinase (JNK), extracellular signal-regulated kinases (ERK1/2) and p38 MAPK pathways $[96,98]$. Activation of the NF- $\mathrm{kB}$ pathway by fungal cell wall components (e.g., mannan, chitin and $\beta$-glucan) is sustained during commensal colonisation, while transient MAPK pathway activity results in the activation of the transcriptional regulator c-Jun in the absence of significant hyphal burdens [96]. Relatively little is known about the epithelial c-Jun response to C. albicans yeast, only that it comprises the predominant epithelial response to the yeast morphology of $C$. albicans, and may therefore be considered as a host response to commensal colonisation [96]. Notably, the weak activation of NF- $\mathrm{KB}, \mathrm{MAPK}$ and PI3K pathways does not result in epithelial damage or the induction of a pro-inflammatory response [96]. 
In contrast, elevated burdens of invasive hyphae trigger the second phase of the biphasic epithelial response, which is characterised by a strong, sustained activation of the p38, JNK and ERK1/2 MAPK pathways, resulting in c-Fos activation via p38 and the subsequent release of proinflammatory cytokines (GM-CSF, G-CSF, IL-6, IL-1 $\alpha$, IL-1 $\beta$ and IL-36) and the recruitment of innate immune cells, including TCR $\alpha \beta(+)$ cells, macrophages and neutrophils [82,96,99-101]. The MAPK phosphatase-1 (MKP1) is also activated via MEK1/2-ERK1/2 and acts as a negative regulator of MAPK signalling by dephosphorylating p38 and JNK [98,102]. Together, the ERK/MKP1 and p38/c-Fos signalling pathways alert surrounding tissues to the presence of invasive $C$. albicans hyphae, a process which has come to be known as the "danger response" [96].

Recently, it was demonstrated that the activation of the epithelial danger response and the damage caused to epithelial cells during C. albicans infection is driven by candidalysin; a cytolytic peptide toxin secreted from C. albicans hyphae $[103,104]$. Candidalysin is encoded by the extent of cell elongation 1 (ECE1) gene and is derived from sequential proteolytic cleavage of its parent protein Ece1p by kexin-like proteinases $[103,105]$. C. albicans mutants lacking ECE1 or candidalysin form hyphae and penetrate epithelial cells normally, but do not activate a pro-inflammatory response or cause epithelial damage. During mucosal infection, it is proposed that candidalysin accumulates in an invasion "pocket" created by the invading hyphae. Once the concentration of candidalysin is sufficiently high it causes calcium influx, release of lactate dehydrogenase and membrane destabilisation; all of which are characteristics of several microbial toxins $[103,106]$. Thus, while epithelial recognition of C. albicans $\beta$-glucan is mediated through the nonclassical PRR EphA2 [93], it is the recognition of candidalysin activity that drives the host proinflammatory response [103]. The epithelial receptors with known ligands involved in the recognition of C. albicans are presented in Table 1.

Table 1. Epithelial receptor-ligand pairings involved in recognition of C. albicans.

\begin{tabular}{ccc}
\hline Receptor & Ligand & Reference \\
\hline Aryl hydrocarbon receptor & IFN- $\gamma$ and L-kynurenine & {$[68]$} \\
Dectin-1 & $\beta$-glucan & {$[90]$} \\
EGFR/Her2 & Als3p/Ssa1p & {$[28,29]$} \\
EphA2 & $\beta$-glucan & {$[93]$} \\
\hline
\end{tabular}

Approximately $75 \%$ of females will experience an episode of vulvovaginal candidiasis (VVC) in their lifetime [107], while approximately $9 \%$ will suffer from recurrent VVC [108]. The symptoms of VVC (itching, burning, pain and discharge) are associated with the recruitment of neutrophils into the vaginal lumen [109]. Recent advances have demonstrated that the immune pathology associated with VVC is driven by the secretion of candidalysin from C. albicans hyphae [104] and the presence of heparan sulphate, which blocks the interaction between neutrophil Mac1 and C. albicans Pra1p required for fungal killing [110,111].

\section{Epithelial Responses to C. albicans}

Mucosal surfaces secrete numerous host defence peptides as part of the innate immune response to $C$. albicans. The most prominent of these include the defensins, cathelicidin, lactoferrin, histatin- 5 and the alarmins S100A8 and S100A9 [112-114]. Defensins are cysteine-rich peptides that can be divided into two families: the $\alpha$-defensins, which are mainly secreted by neutrophils, and the $\beta$-defensins, which are produced from epithelial cells [115]. Recently, however, $\alpha$-defensin six secreted by human intestinal epithelial cells has been shown to inhibit $C$. albicans invasion and biofilm formation [116]. In humans, four $\beta$-defensins are expressed in epithelial cells: hBD-1, hBD-2, hBD-3 and hBD-4 [115,117]. While hBD-1 and hBD- 4 are constitutively expressed, hBD- 2 and hBD- 3 are present at low concentrations and are strongly induced in response to infection or stress [115]. HBD-2 and hBD-3 are found in the human buccal epithelium [118] and are preferentially induced by C. albicans hyphae rather than yeast cells [119]. The antifungal activity of both of these defensins requires binding to the fungal invasin 
Ssa1p [120]. Defensins can also act as chemoattractants for T cells, DCs and neutrophils [120]. Mice deficient in IL-17RA express reduced levels of mBD3 and consequently develop severe OPC [121], underlining the importance of these molecules in the innate response to fungal infection.

LL-37 is the only human cathelicidin identified to date and has a broad spectrum of immune functions including antibacterial action and the ability to induce chemokines. It is a cationic antimicrobial peptide produced by many types of cells including epithelial cells [117]. LL-37 is present in the oral cavity where it inhibits the adherence of $C$. albicans to epithelial cells by interacting with fungal cell wall components such as mannan, chitin and glucan [122].

The S100 alarmins are typically found in the cytoplasm but are released into the extracellular environment following tissue damage. A variety of cell types express S100 alarmins including polymorphonuclear neutrophils, monocytes and epithelial cells. The S100 alarmins produced by vaginal epithelial cells are implicated in the recruitment of innate cells following interaction with C. albicans $[123,124]$. Calprotectin, which constitutes a dimer of S100A8 and S100A9, inhibits C. albicans cell growth $[125,126]$. Lactoferrin also possesses antifungal activity by disrupting the $C$. albicans plasma membrane [127] and inducing iron deprivation [128] within the fungus. Histatin-5 is a histidine-rich cationic peptide secreted by human salivary glands. This peptide interacts with the $\beta$-glucans present in the C. albicans cell wall, binds to the heat shock proteins Ssa1p/2p [129], perturbs the fungal plasma membrane and is translocated into the cytoplasm where it disturbs the balance of cellular ions leading to toxicity [130].

Recent research has demonstrated that epithelial cells express the IL-17 receptor (IL-17R) which binds to IL-17 secreted by multiple lymphoid cells including $\gamma \delta$-T, natural killer T (NKT), innate lymphoid cell type 3 (ILC3) and TCR $\beta+$ 'natural' Th17 cells (nTh17) [131,132]. From the several IL-17 isoforms, only IL-17A and IL-17F seem to be important in mediating antifungal immunity [114,132]. These isoforms trigger the release of the neutrophil activating chemokine G-CSF and $\beta$-defensin- 1 and -3 from epithelial cells in oral tissue and the release of histatins from the salivary glands during OPC [112,133]. Mice lacking IL-17R are highly susceptible to OPC [131]. However, human patients deficient in IL-17 secretion or signalling owing to mutations in IL-17F or IL17RA show high susceptibility to mucosal but not invasive candidiasis suggesting that, in humans, Th17 cell responses are mainly necessary for mucosal antifungal responses [134-136]. Factors involved in the epithelial response to C. albicans are summarised in Table 2.

Table 2. Factors involved in the host epithelial response to C. albicans.

\begin{tabular}{cccc}
\hline Factor & Target & Cell/Tissue & Reference \\
\hline$\alpha$-defensin 6 & Invasion/biofilm formation & Intestinal ECs & {$[116]$} \\
Murine $\beta$-defensin 1 & Reduces mucosal infection & Oral cavity & {$[133]$} \\
$\beta$-defensin 2 & Ssa1p & Buccal epithelium & {$[118,120]$} \\
$\beta$-defensin 3 & Ssa1p & Buccal epithelium & {$[118,120]$} \\
Cathelicidin & Fungal adherence & Oral cavity & {$[122]$} \\
S100 alarmins & Immune cell recruitment & Vaginal ECs & {$[123,124]$} \\
Calprotectin & Fungal cell growth & In vitro & {$[125]$} \\
Lactoferrin & Plasma membrane & In vitro & {$[127]$} \\
Histatin-5 & Ssa1/2p & Salivary gland & {$[129,130]$} \\
\hline
\end{tabular}

\section{Secreted Fungal Factors}

In order to persist in the host $C$. albicans must overcome (or avoid) the host immune response and the various challenges posed by the host niche. C. albicans secretes 225 proteins which facilitate tissue invasion, immune evasion, nutrient acquisition and organ damage [137]. Many of these secreted proteins are enzymes including lipases, phospholipases and Saps [138], which have different substrate specificities and $\mathrm{pH}$ optimums [139]. The best studied of these secreted enzymes are the Saps, which comprise Sap1p to Sap10p $[137,140]$. Sap1-8p are secreted into the extracellular milieu, 
while Sap9p and Sap10p remain anchored on the cell membrane [141]. Sap2p and Sap6p stimulate neutrophil chemotaxis during vaginitis [142].

Collectively, the Saps degrade a wide range of host factors including E-cadherin and several involved in the innate and adaptive immune responses (e.g., complement, histatin- 5 and antibodies), allowing C. albicans to combat host immune defences [140,143]. The amyloidogenic regions within Sap6p contribute to fungal aggregation by binding to zinc and Zap1p-regulated proteins on the hypha surface [144]. Conflicting reports surround the ability of Saps to cause damage to the oral epithelium; while the application of a Sap inhibitor to C. albicans reduced levels of epithelial damage [145], studies with Sap deletion mutant strains did not recapitulate this effect [146].

Although relatively little is known about secreted lipases and phospholipases in comparison to the Saps, both classes of enzyme are associated with C. albicans virulence. Expression of phospholipases is positively correlated with increased epithelial adherence and pathogenicity $[147,148]$. Notably, secretion of phospholipase B1 (Plb1p) contributes to epithelial penetrance and gastrointestinal translocation $[149,150]$, while a $C$. albicans pld1 null mutant forms hyphae in vivo, can adhere to and colonise the murine alimentary tract, but is unable to penetrate the epithelium [151].

C. albicans encodes ten lipases designated Lip1p [152] and Lip2-10p [153], which are differentially expressed during mucosal colonisation and infection [154]. Expression of LIP1-10 is detectable in a reconstituted human oral epithelium infection model after $48 \mathrm{~h}$ [155] while analysis of C. albicans isolated from the saliva of oral candidiasis patients demonstrates that all lipases except LIP10 were expressed across the patient cohort [155].

The host mucosa secretes an array of antimicrobial compounds that function to clear invading pathogens. In response to this secreted armoury, C. albicans can also produce an arsenal of factors to protect itself from this secreted host response. While not secreted per se, Msb2p is a C. albicans cell surface protein that is shed into the extracellular environment where it confers broad-range protection against numerous antimicrobials including LL-37, hBD-1 and histatin-5 [156]. Histatin-5 is also degraded by Sap9p [157] and is actively effluxed from the fungal cell by the polyamine transporter Flu1p [158]. The secreted factors that contribute to C. albicans pathogenicity are depicted in Figure 1D.

\section{Acquisition of Micronutrients}

While often discussed in the context of systemic infection, microbial acquisition of host micronutrients is also important at mucosal surfaces. The concentration of zinc, copper and iron in whole saliva is highly variable between individuals and is influenced by numerous factors including diet, gender, age, general health and lifestyle choices such as smoking [159-162].

Although the gastrointestinal tract receives a steady supply of dietary iron, micronutrients such as zinc are subject to diet-independent changes in availability, for instance, by neutrophil mediated calprotectin-dependent sequestration during gastrointestinal inflammation [163]. Relatively little is known about the concentration of micronutrients at the vaginal mucosa. Throughout the course of host-microbe coevolution, the human host has evolved to withhold specific nutrients from microbes as a defence strategy designed to curtail microbial growth and persistence. To thwart such defences, C. albicans has evolved to express and regulate numerous micronutrient acquisition systems in order to persist in the hostile environment of the human body, whether as a commensal or pathogen.

\subsection{Assimilation of Zinc}

Current research is now unveiling the importance of zinc in the complex relationship between C. albicans and the human host. Under condition in which nutritional immunity is imposed, C. albicans remains capable of acquiring zinc from the host. The $\mathrm{pH}$-regulated antigen-1 (Pra1p) is a secreted zinc-binding "zincophore" that harvests zinc from the host environment before reassociating with the fungal cell and the coexpressed zinc zip-transporter Zrt1p [164]. Sap6p can also bind zinc and is required for zinc uptake and fungal growth in low zinc environments [144]. 
Zinc homeostasis in C. albicans is regulated by the transcriptional activator Zap1p which controls the expression of several genes including the zinc transporters ZRT1-3 and the vacuolar zinc importer ZRC1 $[165,166]$. Conditions of zinc limitation drive the formation of the so-called "Goliath" phenotype, in which C. albicans yeast cells become enlarged and exhibit hyper-adherence to polystyrene [167]. C. albicans Zrt2p is essential for zinc uptake at acidic $\mathrm{pH}$ [168]. Cellular import of zinc is mediated by Zrt1p/Zrt2p while Zrc1p functions during storage of zinc in vesicle-like "zincosomes" [168]. The major factors required for zinc acquisition from the host are depicted in Figure 2A,B.

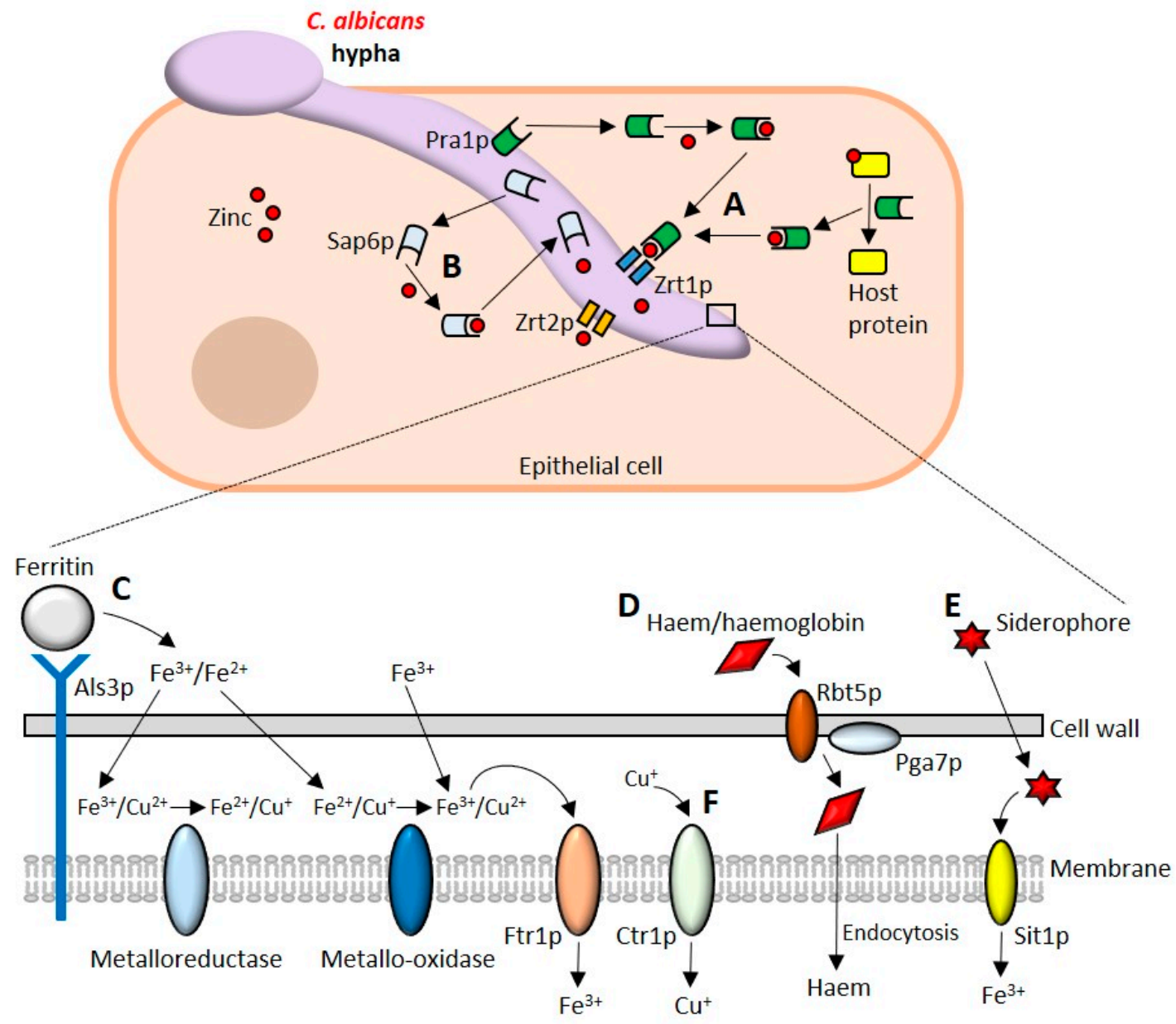

Figure 2. Acquisition of micronutrients by Candida albicans. (A) C. albicans uses the secreted zincophore Pra1p to bind free zinc and scavenge zinc from zinc-containing host proteins. Once zinc is acquired it is imported into the cell by the zinc transporter Zrt1p. Zrt2p is also capable of importing zinc and is essential for zinc uptake at acidic pH. (B) The secreted aspartic proteinase Sap6p is also a zincophore capable of binding and importing zinc. (C) Als3p can bind to host ferritin to release ferric and ferrous ions that are reduced and oxidised by ferric reductases and ferric oxidases, respectively. C. albicans can also acquire free iron which is imported into the cell by Ftr1p. (D) The haemolytic activity of C. albicans liberates haemoglobin from blood. Haemoglobin/haem are bound by the haemoglobin receptor Rbt5p and by Pga7p and endocytosed into the cell. (E) C. albicans can also acquire iron by scavenging siderophores. The ferrichrome transporter Sit1p is used to import ferric ions. (F) Import of copper is mediated by the copper transporter Ctr1p.

\subsection{Iron Uptake}

C. albicans uses three distinct iron uptake systems; haemoglobin uptake, the reductive iron uptake system and scavenging host siderophores [169-172]. C. albicans can lyse erythrocytes to release haemoglobin from blood $[103,173-175]$, which is subsequently bound by the haemoglobin 
receptor Rbt5p (and its homolog Rbt51p), Pga7p and the secreted haemophore Csa2p [176-179]. A coordinated haem "acquisition relay" between Rbt5p and Pga7p facilitates the transport of haem from the extracellular environment into vacuoles of the endocytic pathway $[179,180]$, where it can be further processed for use.

C. albicans uses a reductive uptake system to acquire iron from ferritin, transferrin [181] and ferric ions. Although a receptor for transferrin has not yet been identified, Als3p exhibits ferritin binding activity in addition to its role as an adhesin and invasin [47]. To utilise the iron found in transferrin, the membrane-associated ferric reductases Cfllp and Fre10p reduce $\mathrm{Fe}^{3+}$ to $\mathrm{Fe}^{2+}[181,182]$, which is transported into the cell via a complex comprising an iron permease and a multicopper oxidase [183]. C. albicans possesses four iron permeases-the plasma membrane associated Ftr1p and Ftr2p and the vacuolar associated Fth1 $p$ and Fth2 $p[170,183]$ —and five genes encoding iron ferroxidases, all of which are multicopper oxidases [183-186]. It is predicted that as many as twenty possible iron transporter complexes may be formed to facilitate iron uptake [183]. The importance of copper in the process of high affinity iron transport is highlighted by gene deletion analysis of the copper-transporting P-type ATPase Ccc2p [187]. A C. albicans $c c c 2 \Delta / \Delta$ null mutant is unable to use haem as an iron source but may continue to acquire iron from haemin and haemoglobin [187].

C. albicans uses the ferrichrome siderophore importer protein Sit1p to scavenge siderophores from bacteria and other fungi. Such behaviour is termed 'iron parasitism' and is well documented in numerous microbes $[172,188,189]$. Sit1p is required for epithelial invasion but is dispensable for disseminated infection in vivo [172]. The major iron uptake systems of $C$. albicans are summarised in Figure 2C-E.

The balance between iron uptake and the avoidance of iron-related toxicity is addressed by an elegant tripartite circuit comprising the transcriptional activator Sef1 $\mathrm{p}$ which promotes iron uptake together with Sfu1p and Hap34p which repress transcriptional activation of iron-uptake and utilisation genes, respectively [190]. Together, these factors confer resistance to iron depletion in the systemic compartment while enabling the fungus to avoid iron toxicity during commensal colonisation of the gastrointestinal tract [190].

\subsection{Copper}

C. albicans uses the transcriptional activator Mac1p to activate expression of the high-affinity copper transporter Ctr1p in copper replete environments [191,192]. Once in the cell, $\mathrm{Cu}^{+}$is rapidly bound to intracellular chaperone proteins before being incorporated into copper requiring proteins. Copper is also required for efficient iron uptake as it is incorporated into the multicopper oxidases of C. albicans and a ctr1 null mutant is unable to grow under conditions of copper or iron limitation [191,192]. C. albicans can resist the toxicity associated with the intracellular accumulation of copper ions by activating the copper resistance determinant gene CRD1 (also known as CRP1) encoding a P1-type ATPase copper extrusion pump that removes excess copper ions from the cell $[193,194]$. A C. albicans crd1 null mutant is sensitive to exogenous sources of copper, silver and cadmium, suggesting a degree of functional promiscuity towards the efflux of metal ions [193].

C. albicans Sur7p is a component of the membrane compartment containing Can1 (MCC) plasma membrane subdomain required for appropriate morphogenesis, cell wall synthesis, localisation of actin and responses to cell wall stress [195-198]. Deletion of SUR7 results in an increased sensitivity to copper [199]. More recently, the architecture of the fungal plasma membrane has been shown to play an important role in resistance to copper toxicity. The plasma membrane of $C$. albicans pill $\Delta / \Delta, \operatorname{lsp} 1 \Delta / \Delta$, $\operatorname{ros} 161 \Delta / \Delta, \operatorname{rvs} 167 \Delta / \Delta, \operatorname{arp} 2 \Delta / \Delta$ and $\operatorname{arp} 3 \Delta / \Delta$ mutants are more readily permeabilised by copper and are more susceptible to copper-mediated killing [200]. Copper uptake from the host is depicted in Figure 2F. 


\section{Conclusions}

The mucosal surfaces of the human body have a long-established relationship with C. albicans that continues to evolve. Throughout this evolving relationship, fungal adaptation and the mucosal immune response have provided a fulcrum about which the balance between commensalism and pathogenicity is determined. Although research often highlights the importance of individual factors to mucosal commensalism and pathogenesis, it must be stressed that both are multifactorial processes that draw heavily upon the combined biological output of numerous molecules. As research continues to explore the interface between fungal adaptation and the host mucosal response, our understanding of the events that determine commensalism and pathogenicity at mucosal surfaces will become ever clearer.

Author Contributions: All authors contributed to manuscript preparation. J.P.R. wrote the initial draft. N.O.P., R.B. and J.P.R. contributed to figures and tables. All authors contributed to final editing.

Funding: This work was supported by grants from the Biotechnology \& Biological Sciences Research Council (BB/N014677/1), the National Institutes of Health (R37-DE022550), the King's Health Partners Challenge Fund (R170501), Rosetrees Trust (M680), the NIH Research at Guys and St. Thomas's NHS Foundation Trust, the King's College London Biomedical Research Centre (IS-BRC-1215-20006) and a Wellcome Trust Investigator Award (214229_Z_18_Z) to J.R.N.

Conflicts of Interest: The authors declare no conflicts of interest.

\section{References}

1. Hallen-Adams, H.E.; Suhr, M.J. Fungi in the healthy human gastrointestinal tract. Virulence 2017, 8, 352-358. [CrossRef] [PubMed]

2. Huffnagle, G.B.; Noverr, M.C. The emerging world of the fungal microbiome. Trends Microbiol. 2013, 21, 334-341. [CrossRef] [PubMed]

3. Calderone, R.A.; Fonzi, W.A. Virulence factors of Candida albicans. Trends Microbiol. 2001, 9, $327-335$. [CrossRef]

4. Gulati, M.; Nobile, C.J. Candida albicans biofilms: Development, regulation, and molecular mechanisms. Microbes Infect. 2016, 18, 310-321. [CrossRef] [PubMed]

5. de Repentigny, L.; Aumont, F.; Bernard, K.; Belhumeur, P. Characterization of binding of Candida albicans to small intestinal mucin and its role in adherence to mucosal epithelial cells. Infect. Immun. 2000, 68, 3172-3179. [CrossRef] [PubMed]

6. Williams, D.W.; Jordan, R.P.; Wei, X.Q.; Alves, C.T.; Wise, M.P.; Wilson, M.J.; Lewis, M.A. Interactions of Candida albicans with host epithelial surfaces. J. Oral Microbiol. 2013, 5, 22434. [CrossRef] [PubMed]

7. Hobden, C.; Teevan, C.; Jones, L.; O'Shea, P. Hydrophobic properties of the cell surface of Candida albicans: A role in aggregation. Microbiology 1995, 141 Pt 8, 1875-1881. [CrossRef]

8. Douglas, L.J. Adhesion of Candida species to epithelial surfaces. Crit. Rev. Microbiol. 1987, 15, 27-43. [CrossRef]

9. Hazen, K.C. Participation of yeast cell surface hydrophobicity in adherence of Candida albicans to human epithelial cells. Infect. Immun. 1989, 57, 1894-1900.

10. Hazen, K.C.; Lay, J.G.; Hazen, B.W.; Fu, R.C.; Murthy, S. Partial biochemical characterization of cell surface hydrophobicity and hydrophilicity of Candida albicans. Infect. Immun. 1990, 58, 3469-3476.

11. Jones, D.S.; Schep, L.J.; Shepherd, M.G. The effect of cetylpyridinium chloride (cpc) on the cell surface hydrophobicity and adherence of Candida albicans to human buccal epithelial cells in vitro. Pharm. Res. 1995, 12, 1896-1900. [CrossRef]

12. Skerl, K.G.; Calderone, R.A.; Segal, E.; Sreevalsan, T.; Scheld, W.M. In vitro binding of Candida albicans yeast cells to human fibronectin. Can. J. Microbiol. 1984, 30, 221-227. [CrossRef] [PubMed]

13. Klotz, S.A.; Smith, R.L. A fibronectin receptor on Candida albicans mediates adherence of the fungus to extracellular matrix. J. Infect. Dis. 1991, 163, 604-610. [CrossRef]

14. O'Sullivan, J.M.; Cannon, R.D.; Sullivan, P.A.; Jenkinson, H.F. Identification of salivary basic proline-rich proteins as receptors for Candida albicans adhesion. Microbiology 1997, 143 Pt 2, 341-348. [CrossRef]

15. Enache, E.; Eskandari, T.; Borja, L.; Wadsworth, E.; Hoxter, B.; Calderone, R. Candida albicans adherence to a human oesophageal cell line. Microbiology 1996, 142 Pt 10, 2741-2746. [CrossRef] 
16. Samaranayake, L.P.; MacFarlane, T.W. The effect of dietary carbohydrates on the in-vitro adhesion of Candida albicans to epithelial cells. J. Med. Microbiol. 1982, 15, 511-517. [CrossRef]

17. Hoyer, L.L.; Green, C.B.; Oh, S.H.; Zhao, X. Discovering the secrets of the Candida albicans agglutinin-like sequence $(A L S)$ gene family-A sticky pursuit. Med. Mycol. 2008, 46, 1-15. [CrossRef]

18. Gaur, N.K.; Klotz, S.A. Expression, cloning, and characterization of a Candida albicans gene, ALA1, that confers adherence properties upon Saccharomyces cerevisiae for extracellular matrix proteins. Infect. Immun. 1997, 65, 5289-5294. [PubMed]

19. Gaur, N.K.; Klotz, S.A.; Henderson, R.L. Overexpression of the Candida albicans ALA1 gene in Saccharomyces cerevisiae results in aggregation following attachment of yeast cells to extracellular matrix proteins, adherence properties similar to those of Candida albicans. Infect. Immun. 1999, 67, 6040-6047. [PubMed]

20. Gaur, N.K.; Smith, R.L.; Klotz, S.A. Candida albicans and Saccharomyces cerevisiae expressing ALA1/ALS5 adhere to accessible threonine, serine, or alanine patches. Cell Commun. Adhes. 2002, 9, 45-57. [CrossRef] [PubMed]

21. Rauceo, J.M.; Gaur, N.K.; Lee, K.G.; Edwards, J.E.; Klotz, S.A.; Lipke, P.N. Global cell surface conformational shift mediated by a Candida albicans adhesin. Infect. Immun. 2004, 72, 4948-4955. [CrossRef] [PubMed]

22. Rauceo, J.M.; De Armond, R.; Otoo, H.; Kahn, P.C.; Klotz, S.A.; Gaur, N.K.; Lipke, P.N. Threonine-rich repeats increase fibronectin binding in the Candida albicans adhesin Als5p. Eukaryot. Cell 2006, 5, 1664-1673. [CrossRef] [PubMed]

23. Bois, M.; Singh, S.; Samlalsingh, A.; Lipke, P.N.; Garcia, M.C. Does Candida albicans Als5p amyloid play a role in commensalism in Caenorhabditis elegans? Eukaryot. Cell 2013, 12, 703-711. [CrossRef] [PubMed]

24. Alsteens, D.; Garcia, M.C.; Lipke, P.N.; Dufrene, Y.F. Force-induced formation and propagation of adhesion nanodomains in living fungal cells. Proc. Natl. Acad. Sci. USA 2010, 107, 20744-20749. [CrossRef]

25. Lipke, P.N.; Garcia, M.C.; Alsteens, D.; Ramsook, C.B.; Klotz, S.A.; Dufrene, Y.F. Strengthening relationships: Amyloids create adhesion nanodomains in yeasts. Trends Microbiol. 2012, 20, 59-65. [CrossRef] [PubMed]

26. Cheng, G.; Wozniak, K.; Wallig, M.A.; Fidel, P.L., Jr.; Trupin, S.R.; Hoyer, L.L. Comparison between Candida albicans agglutinin-like sequence gene expression patterns in human clinical specimens and models of vaginal candidiasis. Infect. Immun. 2005, 73, 1656-1663. [CrossRef]

27. Dranginis, A.M.; Rauceo, J.M.; Coronado, J.E.; Lipke, P.N. A biochemical guide to yeast adhesins: Glycoproteins for social and antisocial occasions. Microbiol. Mol. Biol. Rev. 2007, 71, 282-294. [CrossRef] [PubMed]

28. Phan, Q.T.; Myers, C.L.; Fu, Y.; Sheppard, D.C.; Yeaman, M.R.; Welch, W.H.; Ibrahim, A.S.; Edwards, J.E., Jr.; Filler, S.G. Als3 is a Candida albicans invasin that binds to cadherins and induces endocytosis by host cells. PLoS Biol. 2007, 5, e64. [CrossRef]

29. Zhu, W.; Phan, Q.T.; Boontheung, P.; Solis, N.V.; Loo, J.A.; Filler, S.G. EGFR and HER2 receptor kinase signaling mediate epithelial cell invasion by Candida albicans during oropharyngeal infection. Proc. Natl. Acad. Sci. USA 2012, 109, 14194-14199. [CrossRef]

30. Murciano, C.; Moyes, D.L.; Runglall, M.; Tobouti, P.; Islam, A.; Hoyer, L.L.; Naglik, J.R. Evaluation of the role of Candida albicans agglutinin-like sequence (ALS) proteins in human oral epithelial cell interactions. PLoS ONE 2012, 7, e33362. [CrossRef]

31. Laforce-Nesbitt, S.S.; Sullivan, M.A.; Hoyer, L.L.; Bliss, J.M. Inhibition of Candida albicans adhesion by recombinant human antibody single-chain variable fragment specific for Als3p. FEMS Immunol. Med. Microbiol. 2008, 54, 195-202. [CrossRef] [PubMed]

32. Kamai, Y.; Kubota, M.; Kamai, Y.; Hosokawa, T.; Fukuoka, T.; Filler, S.G. Contribution of Candida albicans ALS1 to the pathogenesis of experimental oropharyngeal candidiasis. Infect. Immun. 2002, 70, 5256-5258. [CrossRef] [PubMed]

33. Zhao, X.; Oh, S.H.; Cheng, G.; Green, C.B.; Nuessen, J.A.; Yeater, K.; Leng, R.P.; Brown, A.J.; Hoyer, L.L. ALS3 and ALS8 represent a single locus that encodes a Candida albicans adhesin; functional comparisons between Als3p and Als1p. Microbiology 2004, 150, 2415-2428. [CrossRef] [PubMed]

34. Zhao, X.; Oh, S.H.; Yeater, K.M.; Hoyer, L.L. Analysis of the Candida albicans Als2p and Als4p adhesins suggests the potential for compensatory function within the ALS family. Microbiology 2005, 151, 1619-1630. [CrossRef] [PubMed] 
35. Sohn, K.; Urban, C.; Brunner, H.; Rupp, S. EFG1 is a major regulator of cell wall dynamics in Candida albicans as revealed by DNA microarrays. Mol. Microbiol. 2003, 47, 89-102. [CrossRef] [PubMed]

36. Granger, B.L.; Flenniken, M.L.; Davis, D.A.; Mitchell, A.P.; Cutler, J.E. Yeast wall protein 1 of Candida albicans. Microbiology 2005, 151, 1631-1644. [CrossRef]

37. Granger, B.L. Insight into the antiadhesive effect of yeast wall protein 1 of Candida albicans. Eukaryot. Cell 2012, 11, 795-805. [CrossRef]

38. Zhao, X.; Oh, S.H.; Hoyer, L.L. Deletion of ALS5, ALS6 or ALS7 increases adhesion of Candida albicans to human vascular endothelial and buccal epithelial cells. Med. Mycol. 2007, 45, 429-434. [CrossRef] [PubMed]

39. Sandin, R.L.; Rogers, A.L.; Patterson, R.J.; Beneke, E.S. Evidence for mannose-mediated adherence of Candida albicans to human buccal cells in vitro. Infect. Immun. 1982, 35, 79-85. [PubMed]

40. Willaert, R.G. Adhesins of yeasts: Protein structure and interactions. J. Fungi 2018, 4, 119. [CrossRef] [PubMed]

41. Staab, J.F.; Bahn, Y.S.; Tai, C.H.; Cook, P.F.; Sundstrom, P. Expression of transglutaminase substrate activity on Candida albicans germ tubes through a coiled, disulfide-bonded N-terminal domain of Hwp1 requires C-terminal glycosylphosphatidylinositol modification. J. Biol. Chem. 2004, 279, 40737-40747. [CrossRef]

42. Hoyer, L.L.; Cota, E. Candida albicans agglutinin-like sequence (ALS) family vignettes: A review of ALS protein structure and function. Front. Microbiol. 2016, 7, 280. [CrossRef]

43. Cota, E.; Hoyer, L.L. The Candida albicans agglutinin-like sequence family of adhesins: Functional insights gained from structural analysis. Future Microbiol. 2015, 10. [CrossRef] [PubMed]

44. Silva-Dias, A.; Miranda, I.M.; Branco, J.; Monteiro-Soares, M.; Pina-Vaz, C.; Rodrigues, A.G. Adhesion, biofilm formation, cell surface hydrophobicity, and antifungal planktonic susceptibility: Relationship among Candida spp. Front. Microbiol. 2015, 6, 205. [CrossRef] [PubMed]

45. Gaur, N.K.; Klotz, S.A. Accessibility of the peptide backbone of protein ligands is a key specificity determinant in Candida albicans SRS adherence. Microbiology 2004, 150, 277-284. [CrossRef]

46. Sheppard, D.C.; Yeaman, M.R.; Welch, W.H.; Phan, Q.T.; Fu, Y.; Ibrahim, A.S.; Filler, S.G.; Zhang, M.; Waring, A.J.; Edwards, J.E., Jr. Functional and structural diversity in the ALS protein family of Candida albicans. J. Biol. Chem. 2004, 279, 30480-30489. [CrossRef] [PubMed]

47. Almeida, R.S.; Brunke, S.; Albrecht, A.; Thewes, S.; Laue, M.; Edwards, J.E.; Filler, S.G.; Hube, B. The hyphal-associated adhesin and invasin Als3 of Candida albicans mediates iron acquisition from host ferritin. PLoS Pathog. 2008, 4, e1000217. [CrossRef]

48. Liu, Y.; Mittal, R.; Solis, N.V.; Prasadarao, N.V.; Filler, S.G. Mechanisms of Candida albicans trafficking to the brain. PLoS Pathog. 2011, 7, e1002305. [CrossRef]

49. Salgado, P.S.; Yan, R.; Taylor, J.D.; Burchell, L.; Jones, R.; Hoyer, L.L.; Matthews, S.J.; Simpson, P.J.; Cota, E. Structural basis for the broad specificity to host-cell ligands by the pathogenic fungus Candida albicans. Proc. Natl. Acad. Sci. USA 2011, 108, 15775-15779. [CrossRef] [PubMed]

50. Lin, J.; Oh, S.H.; Jones, R.; Garnett, J.A.; Salgado, P.S.; Rusnakova, S.; Matthews, S.J.; Hoyer, L.L.; Cota, E. The peptide-binding cavity is essential for Als3-mediated adhesion of Candida albicans to human cells. J. Biol. Chem. 2014, 289, 18401-18412. [CrossRef]

51. Hoyer, L.L.; Oh, S.H.; Jones, R.; Cota, E. A proposed mechanism for the interaction between the Candida albicans Als3 adhesin and streptococcal cell wall proteins. Front. Microbiol. 2014, 5, 564. [CrossRef] [PubMed]

52. Klotz, S.A.; Gaur, N.K.; Lake, D.F.; Chan, V.; Rauceo, J.; Lipke, P.N. Degenerate peptide recognition by Candida albicans adhesins Als5p and Als1p. Infect. Immun. 2004, 72, 2029-2034. [CrossRef] [PubMed]

53. Otoo, H.N.; Lee, K.G.; Qiu, W.; Lipke, P.N. Candida albicans Als adhesins have conserved amyloid-forming sequences. Eukaryot. Cell 2008, 7, 776-782. [CrossRef] [PubMed]

54. Lipke, P.N.; Klotz, S.A.; Dufrene, Y.F.; Jackson, D.N.; Garcia-Sherman, M.C. Amyloid-like beta-aggregates as force-sensitive switches in fungal biofilms and infections. Microbiol. Mol. Biol. Rev. 2018, 82, e00035-17. [PubMed]

55. Witchley, J.N.; Penumetcha, P.; Abon, N.V.; Woolford, C.A.; Mitchell, A.P.; Noble, S.M. Candida albicans morphogenesis programs control the balance between gut commensalism and invasive infection. Cell Host Microbe 2019, 25, 432.e6-443.e6. [CrossRef]

56. Prieto, D.; Pla, J. Distinct stages during colonization of the mouse gastrointestinal tract by Candida albicans. Front. Microbiol. 2015, 6, 792. [CrossRef] 
57. Prieto, D.; Roman, E.; Correia, I.; Pla, J. The Hog pathway is critical for the colonization of the mouse gastrointestinal tract by Candida albicans. PLoS ONE 2014, 9, e87128. [CrossRef]

58. Perez, J.C.; Kumamoto, C.A.; Johnson, A.D. Candida albicans commensalism and pathogenicity are intertwined traits directed by a tightly knit transcriptional regulatory circuit. PLoS Biol. 2013, 11, e1001510. [CrossRef] [PubMed]

59. Shao, T.Y.; Ang, W.X.G.; Jiang, T.T.; Huang, F.S.; Andersen, H.; Kinder, J.M.; Pham, G.; Burg, A.R.; Ruff, B.; Gonzalez, T.; et al. Commensal Candida albicans positively calibrates systemic Th17 immunological responses. Cell Host Microbe 2019, 25, 404.e6-417.e6. [CrossRef]

60. Bacher, P.; Hohnstein, T.; Beerbaum, E.; Rocker, M.; Blango, M.G.; Kaufmann, S.; Rohmel, J.; Eschenhagen, P.; Grehn, C.; Seidel, K.; et al. Human anti-fungal Th17 immunity and pathology rely on cross-reactivity against Candida albicans. Cell 2019, 176, 1340.e15-1355.e15. [CrossRef] [PubMed]

61. Pierce, J.V.; Kumamoto, C.A. Variation in candida albicans EFG1 expression enables host-dependent changes in colonizing fungal populations. MBio 2012, 3, e00117-12. [CrossRef] [PubMed]

62. Liang, S.H.; Anderson, M.Z.; Hirakawa, M.P.; Wang, J.M.; Frazer, C.; Alaalm, L.M.; Thomson, G.J.; Ene, I.V.; Bennett, R.J. Hemizygosity enables a mutational transition governing fungal virulence and commensalism. Cell Host Microbe 2019, 25, 418.e6-431.e6. [CrossRef]

63. Pande, K.; Chen, C.; Noble, S.M. Passage through the mammalian gut triggers a phenotypic switch that promotes Candida albicans commensalism. Nat. Genet. 2013, 45, 1088-1091. [CrossRef]

64. Xie, J.; Tao, L.; Nobile, C.J.; Tong, Y.; Guan, G.; Sun, Y.; Cao, C.; Hernday, A.D.; Johnson, A.D.; Zhang, L.; et al. White-opaque switching in natural MTLa/ $\alpha$ isolates of Candida albicans: Evolutionary implications for roles in host adaptation, pathogenesis, and sex. PLoS Biol. 2013, 11, e1001525. [CrossRef] [PubMed]

65. Tso, G.H.W.; Reales-Calderon, J.A.; Tan, A.S.M.; Sem, X.; Le, G.T.T.; Tan, T.G.; Lai, G.C.; Srinivasan, K.G.; Yurieva, M.; Liao, W.; et al. Experimental evolution of a fungal pathogen into a gut symbiont. Science 2018, 362, 589-595. [CrossRef] [PubMed]

66. Moreno-Ruiz, E.; Galan-Diez, M.; Zhu, W.; Fernandez-Ruiz, E.; d’Enfert, C.; Filler, S.G.; Cossart, P.; Veiga, E. Candida albicans internalization by host cells is mediated by a clathrin-dependent mechanism. Cell Microbiol. 2009, 11, 1179-1189. [CrossRef]

67. Atre, A.N.; Surve, S.V.; Shouche, Y.S.; Joseph, J.; Patole, M.S.; Deopurkar, R.L. Association of small Rho GTPases and actin ring formation in epithelial cells during the invasion by Candida albicans. FEMS Immunol. Med. Microbiol. 2009, 55, 74-84. [CrossRef]

68. Solis, N.V.; Swidergall, M.; Bruno, V.M.; Gaffen, S.L.; Filler, S.G. The aryl hydrocarbon receptor governs epithelial cell invasion during oropharyngeal candidiasis. MBio 2017, 8, e00025-17. [CrossRef]

69. Liu, Y.; Shetty, A.C.; Schwartz, J.A.; Bradford, L.L.; Xu, W.; Phan, Q.T.; Kumari, P.; Mahurkar, A.; Mitchell, A.P.; Ravel, J.; et al. New signaling pathways govern the host response to C. albicans infection in various niches. Genome Res. 2015, 25, 679-689. [CrossRef] [PubMed]

70. Nucci, M.; Anaissie, E. Revisiting the source of candidemia: Skin or gut? Clin. Infect. Dis. 2001, 33, $1959-1967$. [CrossRef]

71. Bougnoux, M.E.; Diogo, D.; Francois, N.; Sendid, B.; Veirmeire, S.; Colombel, J.F.; Bouchier, C.; Van Kruiningen, H.; d'Enfert, C.; Poulain, D. Multilocus sequence typing reveals intrafamilial transmission and microevolutions of Candida albicans isolates from the human digestive tract. J. Clin. Microbiol. 2006, 44, 1810-1820. [CrossRef] [PubMed]

72. Gouba, N.; Drancourt, M. Digestive tract mycobiota: A source of infection. Med. Mal. Infect. 2015, 45, 9-16. [CrossRef]

73. Allert, S.; Forster, T.M.; Svensson, C.M.; Richardson, J.P.; Pawlik, T.; Hebecker, B.; Rudolphi, S.; Juraschitz, M.; Schaller, M.; Blagojevic, M.; et al. Candida albicans-induced epithelial damage mediates translocation through intestinal barriers. MBio 2018, 9, e00915-18. [CrossRef] [PubMed]

74. Colina, A.R.; Aumont, F.; Deslauriers, N.; Belhumeur, P.; de Repentigny, L. Evidence for degradation of gastrointestinal mucin by Candida albicans secretory aspartyl proteinase. Infect. Immun. 1996, 64, 4514-4519. [PubMed]

75. Villar, C.C.; Kashleva, H.; Nobile, C.J.; Mitchell, A.P.; Dongari-Bagtzoglou, A. Mucosal tissue invasion by Candida albicans is associated with E-cadherin degradation, mediated by transcription factor Rim101p and protease Sap5p. Infect. Immun. 2007, 75, 2126-2135. [CrossRef] [PubMed] 
76. Dalle, F.; Wachtler, B.; L'Ollivier, C.; Holland, G.; Bannert, N.; Wilson, D.; Labruere, C.; Bonnin, A.; Hube, B. Cellular interactions of Candida albicans with human oral epithelial cells and enterocytes. Cell Microbiol. 2010, 12, 248-271. [CrossRef] [PubMed]

77. Albac, S.; Schmitz, A.; Lopez-Alayon, C.; d'Enfert, C.; Sautour, M.; Ducreux, A.; Labruere-Chazal, C.; Laue, M.; Holland, G.; Bonnin, A.; et al. Candida albicans is able to use M cells as a portal of entry across the intestinal barrier in vitro. Cell Microbiol. 2016, 18, 195-210. [CrossRef] [PubMed]

78. Goyer, M.; Loiselet, A.; Bon, F.; L'Ollivier, C.; Laue, M.; Holland, G.; Bonnin, A.; Dalle, F. Intestinal cell tight junctions limit invasion of Candida albicans through active penetration and endocytosis in the early stages of the interaction of the fungus with the intestinal barrier. PLOS ONE 2016, 11, e0149159. [CrossRef]

79. Pappas, P.G.; Lionakis, M.S.; Arendrup, M.C.; Ostrosky-Zeichner, L.; Kullberg, B.J. Invasive candidiasis. Nat. Rev. Dis. Primers 2018, 4, 18026. [CrossRef]

80. Gow, N.A.; van de Veerdonk, F.L.; Brown, A.J.; Netea, M.G. Candida albicans morphogenesis and host defence: Discriminating invasion from colonization. Nat. Rev. Microbiol. 2011, 10, 112-122. [CrossRef]

81. Underhill, D.M.; Pearlman, E. Immune interactions with pathogenic and commensal fungi: A two-way street. Immunity 2015, 43, 845-858. [CrossRef] [PubMed]

82. Naglik, J.R.; Konig, A.; Hube, B.; Gaffen, S.L. Candida albicans-epithelial interactions and induction of mucosal innate immunity. Curr. Opin. Microbiol. 2017, 40, 104-112. [CrossRef] [PubMed]

83. Ozinsky, A.; Underhill, D.M.; Fontenot, J.D.; Hajjar, A.M.; Smith, K.D.; Wilson, C.B.; Schroeder, L.; Aderem, A. The repertoire for pattern recognition of pathogens by the innate immune system is defined by cooperation between toll-like receptors. Proc. Natl. Acad. Sci. USA 2000, 97, 13766-13771. [CrossRef] [PubMed]

84. Bellocchio, S.; Montagnoli, C.; Bozza, S.; Gaziano, R.; Rossi, G.; Mambula, S.S.; Vecchi, A.; Mantovani, A.; Levitz, S.M.; Romani, L. The contribution of the toll-like/Il-1 receptor superfamily to innate and adaptive immunity to fungal pathogens in vivo. J. Immunol. 2004, 172, 3059-3069. [CrossRef]

85. Netea, M.G.; Gow, N.A.; Munro, C.A.; Bates, S.; Collins, C.; Ferwerda, G.; Hobson, R.P.; Bertram, G.; Hughes, H.B.; Jansen, T.; et al. Immune sensing of Candida albicans requires cooperative recognition of mannans and glucans by lectin and toll-like receptors. J. Clin. Investig. 2006, 116, 1642-1650. [CrossRef]

86. Weindl, G.; Naglik, J.R.; Kaesler, S.; Biedermann, T.; Hube, B.; Korting, H.C.; Schaller, M. Human epithelial cells establish direct antifungal defense through TLR4-mediated signaling. J. Clin. Investig. 2007, 117, 3664-3672. [CrossRef]

87. Weindl, G.; Wagener, J.; Schaller, M. Epithelial cells and innate antifungal defense. J. Dent. Res. 2010, 89, 666-675. [CrossRef]

88. Pinheiro, C.R.; Coelho, A.L.; de Oliveira, C.E.; Gasparoto, T.H.; Garlet, G.P.; Silva, J.S.; Santos, C.F.; Cavassani, K.A.; Hogaboam, C.M.; Campanelli, A.P. Recognition of Candida albicans by gingival fibroblasts: The role of TLR2, TLR4/CD14, and MyD88. Cytokine 2018, 106, 67-75. [CrossRef]

89. Rosentul, D.C.; Delsing, C.E.; Jaeger, M.; Plantinga, T.S.; Oosting, M.; Costantini, I.; Venselaar, H.; Joosten, L.A.; van der Meer, J.W.; Dupont, B.; et al. Gene polymorphisms in pattern recognition receptors and susceptibility to idiopathic recurrent vulvovaginal candidiasis. Front. Microbiol. 2014, 5, 483. [CrossRef]

90. Brown, G.D.; Gordon, S. Immune recognition. A new receptor for beta-glucans. Nature 2001, 413, 36-37. [CrossRef]

91. Taylor, P.R.; Tsoni, S.V.; Willment, J.A.; Dennehy, K.M.; Rosas, M.; Findon, H.; Haynes, K.; Steele, C.; Botto, M.; Gordon, S.; et al. Dectin-1 is required for beta-glucan recognition and control of fungal infection. Nat. Immunol. 2007, 8, 31-38. [CrossRef] [PubMed]

92. Reid, D.M.; Gow, N.A.; Brown, G.D. Pattern recognition: Recent insights from dectin-1. Curr. Opin. Immunol. 2009, 21, 30-37. [CrossRef] [PubMed]

93. Swidergall, M.; Solis, N.V.; Lionakis, M.S.; Filler, S.G. Epha2 is an epithelial cell pattern recognition receptor for fungal beta-glucans. Nat. Microbiol. 2018, 3, 53-61. [CrossRef] [PubMed]

94. Moyes, D.L.; Shen, C.; Murciano, C.; Runglall, M.; Richardson, J.P.; Arno, M.; Aldecoa-Otalora, E.; Naglik, J.R. Protection against epithelial damage during Candida albicans infection is mediated by PI3K/AKT and mammalian target of rapamycin signaling. J. Infect. Dis. 2014, 209, 1816-1826. [CrossRef] [PubMed]

95. Ferwerda, B.; Ferwerda, G.; Plantinga, T.S.; Willment, J.A.; van Spriel, A.B.; Venselaar, H.; Elbers, C.C.; Johnson, M.D.; Cambi, A.; Huysamen, C.; et al. Human dectin-1 deficiency and mucocutaneous fungal infections. N. Engl. J. Med. 2009, 361, 1760-1767. [CrossRef] [PubMed] 
96. Moyes, D.L.; Runglall, M.; Murciano, C.; Shen, C.; Nayar, D.; Thavaraj, S.; Kohli, A.; Islam, A.; Mora-Montes, H.; Challacombe, S.J.; et al. A biphasic innate immune MAPK response discriminates between the yeast and hyphal forms of Candida albicans in epithelial cells. Cell Host Microbe 2010, 8, 225-235. [CrossRef] [PubMed]

97. Moyes, D.L.; Murciano, C.; Runglall, M.; Islam, A.; Thavaraj, S.; Naglik, J.R. Candida albicans yeast and hyphae are discriminated by MAPK signaling in vaginal epithelial cells. PLoS ONE 2011, 6, e26580. [CrossRef]

98. Moyes, D.L.; Richardson, J.P.; Naglik, J.R. Candida albicans-epithelial interactions and pathogenicity mechanisms: Scratching the surface. Virulence 2015, 6, 338-346. [CrossRef] [PubMed]

99. Gladiator, A.; Wangler, N.; Trautwein-Weidner, K.; LeibundGut-Landmann, S. Cutting edge: Il-17-secreting innate lymphoid cells are essential for host defense against fungal infection. J. Immunol. 2013, 190, 521-525. [CrossRef] [PubMed]

100. Verma, A.H.; Richardson, J.P.; Zhou, C.; Coleman, B.M.; Moyes, D.L.; Ho, J.; Huppler, A.R.; Ramani, K.; McGeachy, M.J.; Mufazalov, I.A.; et al. Oral epithelial cells orchestrate innate type 17 responses to Candida albicans through the virulence factor candidalysin. Sci. Immunol. 2017, 2. [CrossRef]

101. Verma, A.H.; Zafar, H.; Ponde, N.O.; Hepworth, O.W.; Sihra, D.; Aggor, F.E.Y.; Ainscough, J.S.; Ho, J.; Richardson, J.P.; Coleman, B.M.; et al. Il-36 and Il-1/Il-17 drive immunity to oral candidiasis via parallel mechanisms. J. Immunol. 2018, 201, 627-634. [CrossRef] [PubMed]

102. Liu, Y.; Shepherd, E.G.; Nelin, L.D. Mapk phosphatases-regulating the immune response. Nat. Rev. Immunol. 2007, 7, 202-212. [CrossRef] [PubMed]

103. Moyes, D.L.; Wilson, D.; Richardson, J.P.; Mogavero, S.; Tang, S.X.; Wernecke, J.; Hofs, S.; Gratacap, R.L.; Robbins, J.; Runglall, M.; et al. Candidalysin is a fungal peptide toxin critical for mucosal infection. Nature 2016, 532, 64-68. [CrossRef] [PubMed]

104. Richardson, J.P.; Willems, H.M.E.; Moyes, D.L.; Shoaie, S.; Barker, K.S.; Tan, S.L.; Palmer, G.E.; Hube, B.; Naglik, J.R.; Peters, B.M. Candidalysin drives epithelial signaling, neutrophil recruitment, and immunopathology at the vaginal mucosa. Infect. Immun. 2018, 86, e00645-17. [CrossRef] [PubMed]

105. Richardson, J.P.; Mogavero, S.; Moyes, D.L.; Blagojevic, M.; Kruger, T.; Verma, A.H.; Coleman, B.M.; De La Cruz Diaz, J.; Schulz, D.; Ponde, N.O.; et al. Processing of Candida albicans Ece1p is critical for candidalysin maturation and fungal virulence. MBio 2018, 9, e02178-17. [CrossRef] [PubMed]

106. Bischofberger, M.; Iacovache, I.; van der Goot, F.G. Pathogenic pore-forming proteins: Function and host response. Cell Host Microbe 2012, 12, 266-275. [CrossRef]

107. Peters, B.M.; Yano, J.; Noverr, M.C.; Fidel, P.L., Jr. Candida vaginitis: When opportunism knocks, the host responds. PLoS Pathog. 2014, 10, e1003965. [CrossRef] [PubMed]

108. Foxman, B.; Muraglia, R.; Dietz, J.P.; Sobel, J.D.; Wagner, J. Prevalence of recurrent vulvovaginal candidiasis in 5 european countries and the united states: Results from an internet panel survey. J. Lower Genit. Tract Dis. 2013, 17, 340-345. [CrossRef]

109. Fidel, P.L., Jr.; Barousse, M.; Espinosa, T.; Ficarra, M.; Sturtevant, J.; Martin, D.H.; Quayle, A.J.; Dunlap, K. An intravaginal live Candida challenge in humans leads to new hypotheses for the immunopathogenesis of vulvovaginal candidiasis. Infect. Immun. 2004, 72, 2939-2946. [CrossRef] [PubMed]

110. Yano, J.; Noverr, M.C.; Fidel, P.L., Jr. Vaginal heparan sulfate linked to neutrophil dysfunction in the acute inflammatory response associated with experimental vulvovaginal candidiasis. MBio 2017, 8, e00211-17. [CrossRef] [PubMed]

111. Yano, J.; Peters, B.M.; Noverr, M.C.; Fidel, P.L., Jr. Novel mechanism behind the immunopathogenesis of vulvovaginal candidiasis: "Neutrophil anergy". Infect. Immun. 2018, 86, e00684-17. [CrossRef]

112. Conti, H.R.; Shen, F.; Nayyar, N.; Stocum, E.; Sun, J.N.; Lindemann, M.J.; Ho, A.W.; Hai, J.H.; Yu, J.J.; Jung, J.W.; et al. Th17 cells and Il-17 receptor signaling are essential for mucosal host defense against oral candidiasis. J. Exp. Med. 2009, 206, 299-311. [CrossRef] [PubMed]

113. Swidergall, M.; Filler, S.G. Oropharyngeal candidiasis: Fungal invasion and epithelial cell responses. PLoS Pathog. 2017, 13, e1006056. [CrossRef] [PubMed]

114. Richardson, J.P.; Moyes, D.L.; Ho, J.; Naglik, J.R. Candida innate immunity at the mucosa. Semin. Cell Dev. Biol. 2018. [CrossRef] [PubMed]

115. Diamond, G.; Ryan, L. Beta-defensins: What are they really doing in the oral cavity? Oral Dis. 2011, 17, 628-635. [CrossRef] [PubMed]

116. Chairatana, P.; Chiang, I.L.; Nolan, E.M. Human alpha-defensin 6 self-assembly prevents adhesion and suppresses virulence traits of Candida albicans. Biochemistry 2017, 56, 1033-1041. [CrossRef] [PubMed] 
117. Hua, X.; Yuan, X.; Tang, X.; Li, Z.; Pflugfelder, S.C.; Li, D.Q. Human corneal epithelial cells produce antimicrobial peptides LL-37 and beta-defensins in response to heat-killed Candida albicans. Ophthalmic Res. 2014, 51, 179-186. [CrossRef] [PubMed]

118. Sawaki, K.; Mizukawa, N.; Yamaai, T.; Fukunaga, J.; Sugahara, T. Immunohistochemical study on expression of alpha-defensin and beta-defensin-2 in human buccal epithelia with candidiasis. Oral Dis. 2002, 8, 37-41. [CrossRef]

119. Feng, Z.; Jiang, B.; Chandra, J.; Ghannoum, M.; Nelson, S.; Weinberg, A. Human beta-defensins: Differential activity against candidal species and regulation by Candida albicans. J. Dent. Res. 2005, 84, 445-450. [CrossRef] [PubMed]

120. Vylkova, S.; Li, X.S.; Berner, J.C.; Edgerton, M. Distinct antifungal mechanisms: Beta-defensins require Candida albicans Ssa1 protein, while Trk1p mediates activity of cysteine-free cationic peptides. Antimicrob. Agents Chemother. 2006, 50, 324-331. [CrossRef] [PubMed]

121. Conti, H.R.; Bruno, V.M.; Childs, E.E.; Daugherty, S.; Hunter, J.P.; Mengesha, B.G.; Saevig, D.L.; Hendricks, M.R.; Coleman, B.M.; Brane, L.; et al. Il-17 receptor signaling in oral epithelial cells is critical for protection against oropharyngeal candidiasis. Cell Host Microbe 2016, 20, 606-617. [CrossRef] [PubMed]

122. Tsai, P.W.; Yang, C.Y.; Chang, H.T.; Lan, C.Y. Human antimicrobial peptide LL-37 inhibits adhesion of Candida albicans by interacting with yeast cell-wall carbohydrates. PLoS ONE 2011, 6, e17755. [CrossRef]

123. Yano, J.; Lilly, E.; Barousse, M.; Fidel, P.L., Jr. Epithelial cell-derived S100 calcium-binding proteins as key mediators in the hallmark acute neutrophil response during Candida vaginitis. Infect. Immun. 2010, 78, 5126-5137. [CrossRef]

124. Yano, J.; Palmer, G.E.; Eberle, K.E.; Peters, B.M.; Vogl, T.; McKenzie, A.N.; Fidel, P.L., Jr. Vaginal epithelial cell-derived S100 alarmins induced by Candida albicans via pattern recognition receptor interactions are sufficient but not necessary for the acute neutrophil response during experimental vaginal candidiasis. Infect. Immun. 2014, 82, 783-792. [CrossRef] [PubMed]

125. Sohnle, P.G.; Hahn, B.L.; Santhanagopalan, V. Inhibition of Candida albicans growth by calprotectin in the absence of direct contact with the organisms. J. Infect. Dis. 1996, 174, 1369-1372. [CrossRef]

126. Kuhbacher, A.; Burger-Kentischer, A.; Rupp, S. Interaction of Candida species with the skin. Microorganisms 2017, 5, 32. [CrossRef] [PubMed]

127. Nikawa, H.; Samaranayake, L.P.; Tenovuo, J.; Pang, K.M.; Hamada, T. The fungicidal effect of human lactoferrin on Candida albicans and Candida krusei. Arch. Oral. Biol. 1993, 38, 1057-1063. [CrossRef]

128. Kirkpatrick, C.H.; Green, I.; Rich, R.R.; Schade, A.L. Inhibition of growth of Candida albicans by iron-unsaturated lactoferrin: Relation to host-defense mechanisms in chronic mucocutaneous candidiasis. J. Infect. Dis. 1971, 124, 539-544. [CrossRef]

129. Li, X.S.; Reddy, M.S.; Baev, D.; Edgerton, M. Candida albicans Ssa1/2p is the cell envelope binding protein for human salivary histatin 5. J. Biol. Chem. 2003, 278, 28553-28561. [CrossRef]

130. Jang, W.S.; Bajwa, J.S.; Sun, J.N.; Edgerton, M. Salivary histatin 5 internalization by translocation, but not endocytosis, is required for fungicidal activity in Candida albicans. Mol. Microbiol. 2010, 77, 354-370. [CrossRef] [PubMed]

131. Conti, H.R.; Peterson, A.C.; Brane, L.; Huppler, A.R.; Hernandez-Santos, N.; Whibley, N.; Garg, A.V.; Simpson-Abelson, M.R.; Gibson, G.A.; Mamo, A.J.; et al. Oral-resident natural Th17 cells and $\gamma \delta$ T cells control opportunistic Candida albicans infections. J. Exp. Med. 2014, 211, 2075-2084. [CrossRef] [PubMed]

132. Huppler, A.R.; Verma, A.H.; Conti, H.R.; Gaffen, S.L. Neutrophils do not express Il-17A in the context of acute oropharyngeal candidiasis. Pathogens 2015, 4, 559-572. [CrossRef] [PubMed]

133. Tomalka, J.; Azodi, E.; Narra, H.P.; Patel, K.; O’Neill, S.; Cardwell, C.; Hall, B.A.; Wilson, J.M.; Hise, A.G. Beta-defensin 1 plays a role in acute mucosal defense against Candida albicans. J. Immunol. 2015, 194, 1788-1795. [CrossRef] [PubMed]

134. Liu, L.; Okada, S.; Kong, X.F.; Kreins, A.Y.; Cypowyj, S.; Abhyankar, A.; Toubiana, J.; Itan, Y.; Audry, M.; Nitschke, P.; et al. Gain-of-function human STAT1 mutations impair Il-17 immunity and underlie chronic mucocutaneous candidiasis. J. Exp. Med. 2011, 208, 1635-1648. [CrossRef]

135. Puel, A.; Cypowyj, S.; Bustamante, J.; Wright, J.F.; Liu, L.; Lim, H.K.; Migaud, M.; Israel, L.; Chrabieh, M.; Audry, M.; et al. Chronic mucocutaneous candidiasis in humans with inborn errors of interleukin-17 immunity. Science 2011, 332, 65-68. [CrossRef] [PubMed] 
136. Netea, M.G.; Joosten, L.A.; van der Meer, J.W.; Kullberg, B.J.; van de Veerdonk, F.L. Immune defence against Candida fungal infections. Nat. Rev. Immunol. 2015, 15, 630-642. [CrossRef] [PubMed]

137. Sorgo, A.G.; Heilmann, C.J.; Brul, S.; de Koster, C.G.; Klis, F.M. Beyond the wall: Candida albicans secret(e)s to survive. FEMS Microbiol. Lett. 2013, 338, 10-17. [CrossRef] [PubMed]

138. Cauchie, M.; Desmet, S.; Lagrou, K. Candida and its dual lifestyle as a commensal and a pathogen. Res. Microbiol. 2017, 168, 802-810. [CrossRef]

139. da Silva Dantas, A.; Lee, K.K.; Raziunaite, I.; Schaefer, K.; Wagener, J.; Yadav, B.; Gow, N.A. Cell biology of Candida albicans -host interactions. Curr. Opin. Microbiol. 2016, 34, 111-118. [CrossRef] [PubMed]

140. Naglik, J.R.; Challacombe, S.J.; Hube, B. Candida albicans secreted aspartyl proteinases in virulence and pathogenesis. Microbiol. Mol. Biol. Rev. 2003, 67, 400-428. [CrossRef] [PubMed]

141. Albrecht, A.; Felk, A.; Pichova, I.; Naglik, J.R.; Schaller, M.; de Groot, P.; Maccallum, D.; Odds, F.C.; Schafer, W.; Klis, F.; et al. Glycosylphosphatidylinositol-anchored proteases of Candida albicans target proteins necessary for both cellular processes and host-pathogen interactions. J. Biol. Chem. 2006, 281, 688-694. [CrossRef]

142. Gabrielli, E.; Sabbatini, S.; Roselletti, E.; Kasper, L.; Perito, S.; Hube, B.; Cassone, A.; Vecchiarelli, A.; Pericolini, E. In vivo induction of neutrophil chemotaxis by secretory aspartyl proteinases of Candida albicans. Virulence 2016, 7, 819-825. [CrossRef]

143. Cassone, A. Vulvovaginal Candida albicans infections: Pathogenesis, immunity and vaccine prospects. BJOG 2015, 122, 785-794. [CrossRef]

144. Kumar, R.; Breindel, C.; Saraswat, D.; Cullen, P.J.; Edgerton, M. Candida albicans Sap6 amyloid regions function in cellular aggregation and zinc binding, and contribute to zinc acquisition. Sci. Rep. 2017, 7, 2908. [CrossRef] [PubMed]

145. Naglik, J.R.; Moyes, D.; Makwana, J.; Kanzaria, P.; Tsichlaki, E.; Weindl, G.; Tappuni, A.R.; Rodgers, C.A.; Woodman, A.J.; Challacombe, S.J.; et al. Quantitative expression of the Candida albicans secreted aspartyl proteinase gene family in human oral and vaginal candidiasis. Microbiology 2008, 154, 3266-3280. [CrossRef]

146. Lermann, U.; Morschhauser, J. Secreted aspartic proteases are not required for invasion of reconstituted human epithelia by Candida albicans. Microbiology 2008, 154, 3281-3295. [CrossRef] [PubMed]

147. Barrett-Bee, K.; Hayes, Y.; Wilson, R.G.; Ryley, J.F. A comparison of phospholipase activity, cellular adherence and pathogenicity of yeasts. J. Gen. Microbiol. 1985, 131, 1217-1221. [CrossRef] [PubMed]

148. Ibrahim, A.S.; Mirbod, F.; Filler, S.G.; Banno, Y.; Cole, G.T.; Kitajima, Y.; Edwards, J.E., Jr.; Nozawa, Y.; Ghannoum, M.A. Evidence implicating phospholipase as a virulence factor of Candida albicans. Infect. Immun. 1995, 63, 1993-1998. [PubMed]

149. Leidich, S.D.; Ibrahim, A.S.; Fu, Y.; Koul, A.; Jessup, C.; Vitullo, J.; Fonzi, W.; Mirbod, F.; Nakashima, S.; Nozawa, Y.; et al. Cloning and disruption of caPLB1, a phospholipase b gene involved in the pathogenicity of Candida albicans. J. Biol. Chem. 1998, 273, 26078-26086. [CrossRef]

150. Mukherjee, P.K.; Seshan, K.R.; Leidich, S.D.; Chandra, J.; Cole, G.T.; Ghannoum, M.A. Reintroduction of the PLB1 gene into Candida albicans restores virulence in vivo. Microbiology 2001, 147, 2585-2597. [CrossRef] [PubMed]

151. Dolan, J.W.; Bell, A.C.; Hube, B.; Schaller, M.; Warner, T.F.; Balish, E. Candida albicans PLD I activity is required for full virulence. Med. Mycol. 2004, 42, 439-447. [CrossRef]

152. Fu, Y.; Ibrahim, A.S.; Fonzi, W.; Zhou, X.; Ramos, C.F.; Ghannoum, M.A. Cloning and characterization of a gene (LIP1) which encodes a lipase from the pathogenic yeast Candida albicans. Microbiology 1997, 143 Pt 2 , 331-340. [CrossRef]

153. Hube, B.; Stehr, F.; Bossenz, M.; Mazur, A.; Kretschmar, M.; Schafer, W. Secreted lipases of Candida albicans: Cloning, characterisation and expression analysis of a new gene family with at least ten members. Arch. Microbiol. 2000, 174, 362-374. [CrossRef] [PubMed]

154. Schofield, D.A.; Westwater, C.; Warner, T.; Balish, E. Differential Candida albicans lipase gene expression during alimentary tract colonization and infection. FEMS Microbiol. Lett. 2005, 244, 359-365. [CrossRef] [PubMed]

155. Stehr, F.; Felk, A.; Gacser, A.; Kretschmar, M.; Mahnss, B.; Neuber, K.; Hube, B.; Schafer, W. Expression analysis of the Candida albicans lipase gene family during experimental infections and in patient samples. FEMS Yeast Res. 2004, 4, 401-408. [CrossRef]

156. Swidergall, M.; Ernst, A.M.; Ernst, J.F. Candida albicans mucin Msb2 is a broad-range protectant against antimicrobial peptides. Antimicrob. Agents Chemother. 2013, 57, 3917-3922. [CrossRef] [PubMed] 
157. Meiller, T.F.; Hube, B.; Schild, L.; Shirtliff, M.E.; Scheper, M.A.; Winkler, R.; Ton, A.; Jabra-Rizk, M.A. A novel immune evasion strategy of Candida albicans: Proteolytic cleavage of a salivary antimicrobial peptide. PLoS ONE 2009, 4, e5039. [CrossRef]

158. Li, R.; Kumar, R.; Tati, S.; Puri, S.; Edgerton, M. Candida albicans Flu1-mediated efflux of salivary histatin 5 reduces its cytosolic concentration and fungicidal activity. Antimicrob. Agents Chemother. 2013, 57, 1832-1839. [CrossRef] [PubMed]

159. Kode, M.A.; Karjodkar, F.R. Estimation of the serum and the salivary trace elements in OSMF patients. J. Clin. Diagn. Res. 2013, 7, 1215-1218. [CrossRef]

160. Kim, Y.J.; Kim, Y.K.; Kho, H.S. Effects of smoking on trace metal levels in saliva. Oral Dis. 2010, 16, 823-830. [CrossRef]

161. Chicharro, J.L.; Serrano, V.; Urena, R.; Gutierrez, A.M.; Carvajal, A.; Fernandez-Hernando, P.; Lucia, A. Trace elements and electrolytes in human resting mixed saliva after exercise. Br. J. Sports Med. 1999, 33, $204-207$. [CrossRef]

162. Olmez, I.; Gulovali, M.C.; Gordon, G.E.; Henkin, R.I. Trace elements in human parotid saliva. Biol. Trace Element Res. 1988, 17, 259-270. [CrossRef]

163. Liu, J.Z.; Jellbauer, S.; Poe, A.J.; Ton, V.; Pesciaroli, M.; Kehl-Fie, T.E.; Restrepo, N.A.; Hosking, M.P.; Edwards, R.A.; Battistoni, A.; et al. Zinc sequestration by the neutrophil protein calprotectin enhances Salmonella growth in the inflamed gut. Cell Host Microbe 2012, 11, 227-239. [CrossRef]

164. Citiulo, F.; Jacobsen, I.D.; Miramon, P.; Schild, L.; Brunke, S.; Zipfel, P.; Brock, M.; Hube, B.; Wilson, D. Candida albicans scavenges host zinc via Pra1 during endothelial invasion. PLoS Pathog. 2012, 8, e1002777. [CrossRef]

165. Kim, M.J.; Kil, M.; Jung, J.H.; Kim, J. Roles of zinc-responsive transcription factor Csr1 in filamentous growth of the pathogenic yeast Candida albicans. J. Microbiol. Biotechnol. 2008, 18, 242-247. [PubMed]

166. Nobile, C.J.; Nett, J.E.; Hernday, A.D.; Homann, O.R.; Deneault, J.S.; Nantel, A.; Andes, D.R.; Johnson, A.D.; Mitchell, A.P. Biofilm matrix regulation by Candida albicans Zap1. PLoS Biol. 2009, 7, e1000133. [CrossRef]

167. Malavia, D.; Lehtovirta-Morley, L.E.; Alamir, O.; Weiss, E.; Gow, N.A.R.; Hube, B.; Wilson, D. Zinc limitation induces a hyper-adherent goliath phenotype in Candida albicans. Front. Microbiol. 2017, 8, 2238. [CrossRef] [PubMed]

168. Crawford, A.C.; Lehtovirta-Morley, L.E.; Alamir, O.; Niemiec, M.J.; Alawfi, B.; Alsarraf, M.; Skrahina, V.; Costa, A.; Anderson, A.; Yellagunda, S.; et al. Biphasic zinc compartmentalisation in a human fungal pathogen. PLoS Pathog. 2018, 14, e1007013. [CrossRef]

169. Moors, M.A.; Stull, T.L.; Blank, K.J.; Buckley, H.R.; Mosser, D.M. A role for complement receptor-like molecules in iron acquisition by Candida albicans. J. Exp. Med. 1992, 175, 1643-1651. [CrossRef]

170. Ramanan, N.; Wang, Y. A high-affinity iron permease essential for Candida albicans virulence. Science 2000, 288, 1062-1064. [CrossRef]

171. Lesuisse, E.; Knight, S.A.; Camadro, J.M.; Dancis, A. Siderophore uptake by Candida albicans: Effect of serum treatment and comparison with Saccharomyces cerevisiae. Yeast 2002, 19, 329-340. [CrossRef] [PubMed]

172. Heymann, P.; Gerads, M.; Schaller, M.; Dromer, F.; Winkelmann, G.; Ernst, J.F. The siderophore iron transporter of Candida albicans (Sit1p/Arn1p) mediates uptake of ferrichrome-type siderophores and is required for epithelial invasion. Infect. Immun. 2002, 70, 5246-5255. [CrossRef] [PubMed]

173. Manns, J.M.; Mosser, D.M.; Buckley, H.R. Production of a hemolytic factor by Candida albicans. Infect. Immun. 1994, 62, 5154-5156. [PubMed]

174. Watanabe, T.; Takano, M.; Murakami, M.; Tanaka, H.; Matsuhisa, A.; Nakao, N.; Mikami, T.; Suzuki, M.; Matsumoto, T. Characterization of a haemolytic factor from Candida albicans. Microbiology 1999, 145 Pt 3 , 689-694. [CrossRef]

175. Luo, G.; Samaranayake, L.P.; Yau, J.Y. Candida species exhibit differential in vitro hemolytic activities. J. Clin. Microbiol. 2001, 39, 2971-2974. [CrossRef]

176. Weissman, Z.; Kornitzer, D. A family of Candida cell surface haem-binding proteins involved in haemin and haemoglobin-iron utilization. Mol. Microbiol. 2004, 53, 1209-1220. [CrossRef] [PubMed]

177. Nasser, L.; Weissman, Z.; Pinsky, M.; Amartely, H.; Dvir, H.; Kornitzer, D. Structural basis of haem-iron acquisition by fungal pathogens. Nat. Microbiol. 2016, 1, 16156. [CrossRef] [PubMed]

178. Sorgo, A.G.; Heilmann, C.J.; Dekker, H.L.; Brul, S.; de Koster, C.G.; Klis, F.M. Mass spectrometric analysis of the secretome of Candida albicans. Yeast 2010, 27, 661-672. [CrossRef] 
179. Kuznets, G.; Vigonsky, E.; Weissman, Z.; Lalli, D.; Gildor, T.; Kauffman, S.J.; Turano, P.; Becker, J.; Lewinson, O.; Kornitzer, D. A relay network of extracellular heme-binding proteins drives C. albicans iron acquisition from hemoglobin. PLoS Pathog. 2014, 10, e1004407. [CrossRef]

180. Weissman, Z.; Shemer, R.; Conibear, E.; Kornitzer, D. An endocytic mechanism for haemoglobin-iron acquisition in Candida albicans. Mol. Microbiol. 2008, 69, 201-217. [CrossRef]

181. Knight, S.A.; Vilaire, G.; Lesuisse, E.; Dancis, A. Iron acquisition from transferrin by Candida albicans depends on the reductive pathway. Infect. Immun. 2005, 73, 5482-5492. [CrossRef]

182. Hammacott, J.E.; Williams, P.H.; Cashmore, A.M. Candida albicans Cfl1 encodes a functional ferric reductase activity that can rescue a Saccharomyces cerevisiae fre1 mutant. Microbiology 2000, 146 Pt 4, 869-876. [CrossRef]

183. Mamouei, Z.; Zeng, G.; Wang, Y.M.; Wang, Y. Candida albicans possess a highly versatile and dynamic high-affinity iron transport system important for its commensal-pathogenic lifestyle. Mol. Microbiol. 2017, 106, 986-998. [CrossRef] [PubMed]

184. Knight, S.A.; Lesuisse, E.; Stearman, R.; Klausner, R.D.; Dancis, A. Reductive iron uptake by Candida albicans: Role of copper, iron and the Tup1 regulator. Microbiology 2002, 148, 29-40. [CrossRef]

185. Eck, R.; Hundt, S.; Hartl, A.; Roemer, E.; Kunkel, W. A multicopper oxidase gene from Candida albicans: Cloning, characterization and disruption. Microbiology 1999, 145 Pt 9, 2415-2422. [CrossRef]

186. Ziegler, L.; Terzulli, A.; Gaur, R.; McCarthy, R.; Kosman, D.J. Functional characterization of the ferroxidase, permease high-affinity iron transport complex from Candida albicans. Mol. Microbiol. 2011, 81, 473-485. [CrossRef] [PubMed]

187. Weissman, Z.; Shemer, R.; Kornitzer, D. Deletion of the copper transporter caCCC2 reveals two distinct pathways for iron acquisition in Candida albicans. Mol. Microbiol. 2002, 44, 1551-1560. [CrossRef] [PubMed]

188. Hu, C.J.; Bai, C.; Zheng, X.D.; Wang, Y.M.; Wang, Y. Characterization and functional analysis of the siderophore-iron transporter caArn1p in Candida albicans. J. Biol. Chem. 2002, 277, 30598-30605. [CrossRef] [PubMed]

189. Wandersman, C.; Delepelaire, P. Bacterial iron sources: From siderophores to hemophores. Annu. Rev. Microbiol. 2004, 58, 611-647. [CrossRef] [PubMed]

190. Chen, C.; Pande, K.; French, S.D.; Tuch, B.B.; Noble, S.M. An iron homeostasis regulatory circuit with reciprocal roles in Candida albicans commensalism and pathogenesis. Cell Host Microbe 2011, 10, 118-135. [CrossRef] [PubMed]

191. Marvin, M.E.; Williams, P.H.; Cashmore, A.M. The Candida albicans CTR1 gene encodes a functional copper transporter. Microbiology 2003, 149, 1461-1474. [CrossRef]

192. Marvin, M.E.; Mason, R.P.; Cashmore, A.M. The caCTR1 gene is required for high-affinity iron uptake and is transcriptionally controlled by a copper-sensing transactivator encoded by caMAC1. Microbiology 2004, 150, 2197-2208. [CrossRef] [PubMed]

193. Riggle, P.J.; Kumamoto, C.A. Role of a Candida albicans P1-type ATPase in resistance to copper and silver ion toxicity. J. Bacteriol. 2000, 182, 4899-4905. [CrossRef]

194. Weissman, Z.; Berdicevsky, I.; Cavari, B.Z.; Kornitzer, D. The high copper tolerance of Candida albicans is mediated by a P-type ATPase. Proc. Natl. Acad. Sci. USA 2000, 97, 3520-3525. [CrossRef] [PubMed]

195. Alvarez, F.J.; Douglas, L.M.; Konopka, J.B. The Sur7 protein resides in punctate membrane subdomains and mediates spatial regulation of cell wall synthesis in Candida albicans. Commun. Integr. Biol. 2009, 2, 76-77. [CrossRef] [PubMed]

196. Alvarez, F.J.; Douglas, L.M.; Rosebrock, A.; Konopka, J.B. The Sur7 protein regulates plasma membrane organization and prevents intracellular cell wall growth in Candida albicans. Mol. Biol. Cell 2008, 19, 5214-5225. [CrossRef]

197. Bernardo, S.M.; Lee, S.A. Candida albicans Sur7 contributes to secretion, biofilm formation, and macrophage killing. BMC Microbiol. 2010, 10, 133. [CrossRef] [PubMed]

198. Wang, H.X.; Douglas, L.M.; Aimanianda, V.; Latge, J.P.; Konopka, J.B. The Candida albicans Sur7 protein is needed for proper synthesis of the fibrillar component of the cell wall that confers strength. Eukaryot. Cell 2011, 10, 72-80. [CrossRef] [PubMed] 
199. Douglas, L.M.; Wang, H.X.; Keppler-Ross, S.; Dean, N.; Konopka, J.B. Sur7 promotes plasma membrane organization and is needed for resistance to stressful conditions and to the invasive growth and virulence of Candida albicans. MBio 2012, 3, e00254-11. [CrossRef] [PubMed]

200. Douglas, L.M.; Konopka, J.B. Plasma membrane architecture protects Candida albicans from killing by copper. PLoS Genet. 2019, 15, e1007911. [CrossRef]

(C) 2019 by the authors. Licensee MDPI, Basel, Switzerland. This article is an open access article distributed under the terms and conditions of the Creative Commons Attribution (CC BY) license (http://creativecommons.org/licenses/by/4.0/). 